\title{
Tim-3-Expressing $\mathrm{CD}^{+}$and $\mathrm{CD}^{+} \mathrm{T}^{\mathrm{T}}$ Cells in Human Tuberculosis (TB) Exhibit Polarized Effector Memory Phenotypes and Stronger Anti-TB Effector Functions
}

\author{
Yueqin Qiu ${ }^{1,29}$, Jianbo Chen ${ }^{39}$, Hongying Liao ${ }^{4}$, Yan Zhang ${ }^{5}$, Hua Wang ${ }^{6}$, Shaoyuan Li', Yanfen Luo ${ }^{1}$, \\ Danyun Fang ${ }^{1}$, Guobao Li ${ }^{7}$, Boping Zhou ${ }^{8}$, Ling Shen ${ }^{9}$, Crystal Y. Chen ${ }^{10}$, Dan Huang ${ }^{10}$, Jiye Cai ${ }^{2}$, \\ Kaiyuan $\mathrm{CaO}^{1}$, Lifang Jiang ${ }^{1}$, Gucheng Zeng ${ }^{1 *}$, Zheng W. Chen ${ }^{10}$
}

1 Department of Microbiology, Zhongshan School of Medicine, Key Laboratory for Tropical Diseases Control of the Ministry of Education, Sun Yat-sen University, Guangzhou, China, 2 College of Life Sciences, Jinan University, Guangzhou, China, 3 Division of Infection and Immunity, Department for Clinical Microbiological Assays, Shenzhen Third People's Hospital, Shenzhen, China, $\mathbf{4}$ Department of Thoracic Surgery, The Third Affiliated Hospital of Sun Yat-sen University, Guangzhou, China, $\mathbf{5}$ Key Laboratory of Gene Engineering of the Ministry of Education, State Key Laboratory of Biocontrol, School of Life Sciences, Sun Yat-sen University, Guangzhou, China, 6 Department of Oral and Maxillofacial Surgery, Hospital of Stomotology, Guanghua School of Stomotology, Sun Yat-sen University, Guangzhou, China, 7 Department of Pulmonary Diseases, Shenzhen Third People's Hospital, Shenzhen, China, 8 Shenzhen Institute of Hepatology, Shenzhen Third People's Hospital, Shenzhen, China, 9 Harvard Medical School, Beth Israel Deaconess Medical Center, Boston, Massachusetts, United States of America, 10 Department of Microbiology and Immunology, Center for Primate Biomedical Research, University of Illinois College of Medicine, Chicago, Illinois, United States of America

\begin{abstract}
T-cell immune responses modulated by T-cell immunoglobulin and mucin domain-containing molecule 3 (Tim-3) during Mycobacterium tuberculosis (Mtb) infection in humans remain poorly understood. Here, we found that active TB patients exhibited increases in numbers of Tim-3-expressing $\mathrm{CD} 4^{+}$and $\mathrm{CD} 8^{+} \mathrm{T}$ cells, which preferentially displayed polarized effector memory phenotypes. Consistent with effector phenotypes, Tim $-3^{+} \mathrm{CD} 4^{+}$and $\mathrm{Tim}-3^{+} \mathrm{CD} 8^{+} \mathrm{T}$-cell subsets showed greater effector functions for producing Th1/Th22 cytokines and CTL effector molecules than Tim- $3^{-}$counterparts, and Tim-3expressing T cells more apparently limited intracellular Mtb replication in macrophages. The increased effector functions for Tim-3-expressing $\mathrm{T}$ cells consisted with cellular activation signaling as Tim- $3^{+} \mathrm{CD} 4^{+}$and $\mathrm{Tim}-3^{+} \mathrm{CD} 8^{+} \mathrm{T}$-cell subsets expressed much higher levels of phosphorylated signaling molecules p38, stat3, stat5, and Erk1/2 than Tim-3- controls. Mechanistic experiments showed that siRNA silencing of Tim-3 or soluble Tim-3 treatment interfering with membrane Tim-3-ligand interaction reduced de novo production of IFN- $\gamma$ and TNF- $\alpha$ by Tim-3-expressing T cells. Furthermore, stimulation of Tim-3 signaling pathways by antibody cross-linking of membrane Tim-3 augmented effector function of IFN- $\gamma$ production by CD4 ${ }^{+}$ and $\mathrm{CD}^{+} \mathrm{T}$ cells, suggesting that Tim-3 signaling helped to drive stronger effector functions in active TB patients. This study therefore uncovered a previously unknown mechanism for T-cell immune responses regulated by Tim-3, and findings may have implications for potential immune intervention in TB.
\end{abstract}

Citation: Qiu Y, Chen J, Liao H, Zhang Y, Wang H, et al. (2012) Tim-3-Expressing CD4 ${ }^{+}$and CD8 ${ }^{+}$T Cells in Human Tuberculosis (TB) Exhibit Polarized Effector Memory Phenotypes and Stronger Anti-TB Effector Functions. PLoS Pathog 8(11): e1002984. doi:10.1371/journal.ppat.1002984

Editor: David M. Lewinsohn, Portland VA Medical Center/Oregon Health and Science University, United States of America

Received April 11, 2012; Accepted September 7, 2012; Published November 8, 2012

Copyright: $\odot 2012$ Qiu et al. This is an open-access article distributed under the terms of the Creative Commons Attribution License, which permits unrestricted use, distribution, and reproduction in any medium, provided the original author and source are credited.

Funding: This work was supported by National Natural Science Foundation of China (NSFC, www.nsfc.gov.cn) (31170847, to G.Z.), US-China Biomedical Collaborative Research Program grant (NIH HL064560-S1, to Z.W.C., www.nih.gov), US-China Cooperation Project of NSFC (www.nsfc.gov.cn) (31129002, to Z.W.C.), national 973 project (2010CB833603, to J.C., www.most.gov.cn), NIH R01 grant HL64560 (to ZWC), NIH R01 grant RR13601 (to ZWC), Shenzhen Key Fund for Emerging Infectious Diseases and Key Fund for Shenzhen Infection and Immunity Laboratory. G.Z. is also supported by the Fundamental Research Funds for the Central Universities of the Ministry of Education of China (www.moe.gov.cn). The funders had no role in study design, data collection and analysis, decision to publish, or preparation of the manuscript.

Competing Interests: The authors have declared that no competing interests exist.

*E-mail: zenggch@mail.sysu.edu.cn

9 These authors contributed equally to this work.

\section{Introduction}

Tuberculosis (TB), an infectious disease caused by Mycobacterium tuberculosis (Mtb) infection, remains a leading cause of morbidity and mortality worldwide [1]. $\mathrm{CD}^{+}$and $\mathrm{CD}^{+} \mathrm{T}$ cells may be important for host immune resistance to TB in humans $[2,3,4,5]$. In mouse models of Mtb infection, IFN- $\gamma$ and TNF- $\alpha$ produced by $\mathrm{CD}^{+}$and $\mathrm{CD}^{+} \mathrm{T}$ cells have been shown to be critical for immune control of Mtb infection [2,4,5]. In addition, $\mathrm{CD}^{+} \mathrm{T}$ cells may contribute to anti-Mtb immunity through releasing bactericidal molecule granulysin or cytotoxic molecules perforin and granzymes killing of Mtb-infected target cells [2,4,5,6]. It is likely that $\mathrm{CD}^{+}$and $\mathrm{CD}^{+}$T-cell effector functions producing Thl or cytotoxic cytokines are required to mount anti-mycobacterial immunity $[2,4,5]$. In this context, insufficiency or failure to mount anti-mycobacterial effector functions by $\mathrm{CD} 4^{+}$and $\mathrm{CD}^{+} \mathrm{T}$ cells may lead to impaired immunity against TB [2]. Therefore, it is important to elucidate functional characteristics and regulatory pathways for Mtb-specific $\mathrm{CD} 4^{+}$and $\mathrm{CD}^{+} \mathrm{T}$ cells during immune responses to Mtb infection.

T-cell immunoglobulin and mucin domain-containing molecule 3 (Tim-3) is a membrane protein initially identified as a 


\section{Author Summary}

Tuberculosis (TB), an infectious disease caused by Mycobacterium tuberculosis (Mtb) infection, remains a leading cause of morbidity and mortality worldwide. While $C D 4^{+}$ and $\mathrm{CD}^{+}$T-cell effector functions producing Th1 or cytotoxic cytokines are required to mount anti-mycobacterial immunity, insufficiency or failure to mount antimycobacterial effector functions by $\mathrm{CD}^{+}$and $\mathrm{CD}^{+}{ }^{+}$cells may lead to impaired immunity against TB. Therefore, it is important to elucidate functional characteristics and regulatory pathways for Mtb-specific $\mathrm{CD}_{4}^{+}$and $\mathrm{CD}^{+} \mathrm{T}$ cells during immune responses to Mtb infection. It was postulated that T-cell immunoglobulin and mucin domaincontaining molecule 3 (Tim-3) might represent a T-cell exhaustion marker, and expression of Tim-3 on T cells may be linked to progressive loss of secretion of cytokines. Thus, Tim-3 expression on T cells might correlate with Tcell dysfunction and disease pathogenic events. However, T-cell immune responses modulated by Tim-3 in human TB disease remain poorly understood. Here, we found that up-regulation of Tim-3 expression in active human TB disease allows $\mathrm{CD}^{+}$and $\mathrm{CD} 8^{+} \mathrm{T}$ cells to mount stronger, but not impaired, anti-mycobacterium effector functions. This study therefore uncovers a previously unknown mechanism for T-cell immune responses regulated by Tim-3, and has an important implication for TB diagnostics and therapy.

negative regulator of Thl immunity in mice $[7,8,9]$. It was postulated that Tim-3, like other members of T-cell inhibitory molecules such as programmed death 1 (PD-1) [10,11,12] and co-stimulatory receptor cytotoxic T-lymphocyte antigen-4 (CTLA-4) [13], might represent a T-cell exhaustion marker $[12,14,15,16,17,18,19,20]$. A number of studies have suggested that abundant expression of Tim-3 on T cells may be linked to progressive loss of secretion of cytokines such as IL-2, TNF- $\alpha$ and IFN- $\gamma$ in viral infections $[15,16,19,21,22]$ or tumors $[23,24]$. Thus, Tim-3 expression on $\mathrm{T}$ cells might correlate with T-cell dysfunction and disease pathogenic events. We have recently shown that Mtb infection can induce significant up-regulation of Tim-3 expression in macaques [25], suggesting that Tim-3 might be involved in host immune responses during Mtb infection in primates. However, it is not known whether Tim-3 expression or Tim-3 pathway plays a role in modulating $\mathrm{T}$-cell immune responses during Mtb infection in macaques and humans. Elucidating how Tim-3 regulates antiMtb effector functions of $\mathrm{CD}^{+}$and $\mathrm{CD}^{+} \mathrm{T}$ cells in human TB will help to understand TB immunopathogenesis and have some implications for immune intervention in TB.

Given that Mtb-specific $\mathrm{CD} 4^{+}$and $\mathrm{CD}^{+} \mathrm{T}$-cell responses are important for anti-mycobacterial immunity, and that $\mathrm{Mtb}$ infection drives up-regulation of Tim-3 capable of regulating T-cell effector functions, we hypothesize that Tim-3-expressing $\mathrm{CD}^{+}$and $\mathrm{CD}^{+}{ }^{+} \mathrm{T}$-cell subpopulations may play a role in modulating host immune responses during Mtb infection in humans. In the current study, we examined the expression of Tim-3 in TB patients in the context of functional characteristics of Mtb-specific CD4 ${ }^{+}$and $\mathrm{CD} 8^{+} \mathrm{T}$ cells. Surprisingly, we found that Tim-3-expressing $\mathrm{CD}^{+}$and $\mathrm{CD}^{+} \mathrm{T}$ cells in active $\mathrm{TB}$ patients exhibit polarized effector memory phenotypes and stronger but not impaired anti-mycobacterium effector functions. Our findings therefore may implicate a new paradigm for $\mathrm{T}$-cell immune responses regulated by Tim-3 expression in human TB.

\section{Results}

Active TB patients exhibited up-regulation of expression of Tim-3 or Galectin-9 (Gal-9) and increases in numbers of Tim-3 or Gal-9-expressing $\mathrm{CD}^{+}$and $\mathrm{CD}^{+}{ }^{+}$cells

We previously demonstrated that Mtb infection induced upregulation of Tim-3 expression in nonhuman primates [25]. As an initial step to characterize potential roles of Tim-3 expression in human $\mathrm{TB}$, we performed ex vivo polychromatic flow cytometric analysis in 9 healthy controls (HCs), 30 subjects with latent TB infection (LTBI), and 30 untreated active TB patients (Clinical characteristics of the enrolled subjects with LTBI or active TB disease were shown in Supporting information, Table S1). Active TB was confirmed based on assessment of clinical syndromes, chest radiography, and acid-fast bacilli (AFB) staining in sputum, culture isolation of Mtb and PCR detection of Mtb genes [26]. Peripheral blood mononuclear cells (PBMC) isolated from healthy controls (HCs) or subjects with LTBI or active TB disease were stimulated ex vivo first with pooled Mtb Antigen 85-b (Ag85-b)/ $6 \mathrm{kDa}$ early secretory antigenic target (ESAT-6) peptides (Mtb peptide pool) and then stained for Tim-3 and Gal-9, the only known ligand of Tim-3, or stained directly for Tim-3 or Gal-9 without peptide stimulation. In agreement with TB-driven upregulation of Tim-3 and Gal-9 in Mtb-infected macaques [25], we found up-regulation of Tim-3 and Gal-9 and significant increases in numbers of Tim-3 or Gal-9-expressing $\mathrm{CD}^{+}$and $\mathrm{CD}^{+} \mathrm{T}$ cells in active $\mathrm{TB}$ patients when compared with HCs(Figure 1 and Supporting Information, Figure S1). Interestingly, Mtb peptide stimulation drove further increases in numbers of Tim-3 or Gal-9-expressing $\mathrm{CD}_{4}^{+}$and $\mathrm{CD}^{+} \mathrm{T}$ cells (Figure 1 and Supporting Information, Figure S1). The mean percentages of Tim-3-expressing $\mathrm{CD}^{+}{ }^{+}$(or $\mathrm{CD}^{+}$) $\mathrm{T}$ cells in PBMC of active TB disease and LTBI after Mtb peptide stimulation were increased approximately $9.3 \%$ and $3.0 \%$ (or $8.9 \%$ and $2.8 \%$ ) more than those without Mtb peptide stimulation, respectively (Figure 1).These results suggested that active TB up-regulated Tim-3 and drove increases in numbers of Tim-3+CD $4^{+}$and $\mathrm{CD} 8^{+} \mathrm{T}$ cells.

\section{Tim-3-expressing $\mathrm{CD} 4^{+}$and $\mathrm{CD} 8^{+} \mathrm{T}$ cells in active $\mathrm{TB}$ patients preferentially displayed effector memory, but not central memory, phenotypes}

To characterize phenotypic and functional profiles of Tim-3expressing $\mathrm{CD}^{+}$and $\mathrm{CD}^{+}{ }^{+} \mathrm{T}$ cells, we first examined whether Tim-3 was predominantly expressed in effector memory or central memory/naive T-cell subsets in active $\mathrm{TB}$. Blood $\mathrm{CD}^{+}$or $\mathrm{CD}^{+}$ $\mathrm{T}$ cells from untreated active TB patients $(\mathrm{n}=9)$ were co-stained for Tim-3 and naïve/memory markers in presence or absence of $e x$ vivo antigenic stimulation by Mtb peptide pool, and then analyzed by polychromatic flow cytometry. Based on differential expression of CD45RA and CCR7 [27,28,29], 4 distinct T cell populations were classified as naïve $T$ cells $\left(T_{\text {naive }}, \mathrm{CD} 45 \mathrm{RA} \mathrm{A}^{+} \mathrm{CCR} 7^{+}\right)$, central memory $\mathrm{T}$ cells $\left(\mathrm{T}_{\mathrm{CM}}, \mathrm{CD} 45 \mathrm{RA}^{-} \mathrm{CCR} 7^{+}\right)$, effector memory $\mathrm{T}$ cells $\left(\mathrm{T}_{\mathrm{EM}}, \mathrm{CD} 45 \mathrm{RA}^{-} \mathrm{CCR} 7^{-}\right.$), and $\mathrm{RA}^{+} \mathrm{T}_{\mathrm{EM}}$ ( $\mathrm{T}_{\mathrm{EMRA}}$, also known as terminally differentiated; $\mathrm{CD} 45 \mathrm{RA}^{+} \mathrm{CCR} 7^{-}$) cells. We found that most of Tim-3-expressing $\mathrm{CD}^{+}$and $\mathrm{CD}^{+}{ }^{+} \mathrm{T}$ cells freshly isolated from TB patients or stimulated ex vivo with Mtb peptide pool displayed CD45RA ${ }^{-} \mathrm{CCR} 7^{-} \mathrm{T}_{\mathrm{EM}}$ phenotype, but not CD45RA ${ }^{+} \mathrm{CCR} 7^{+} \mathrm{T}_{\text {naive }}$ or $\mathrm{CD} 45 \mathrm{RA}^{-} \mathrm{CCR} 7^{+} \mathrm{T}_{\mathrm{CM}}$ phenotype(Supporting Information, Figure S2), suggesting a polarization of effector memory phenotype for Tim-3-expressing $\mathrm{CD}^{+}$and $\mathrm{CD}^{+} \mathrm{T}$ cells in active $\mathrm{TB}$ patients. 
A

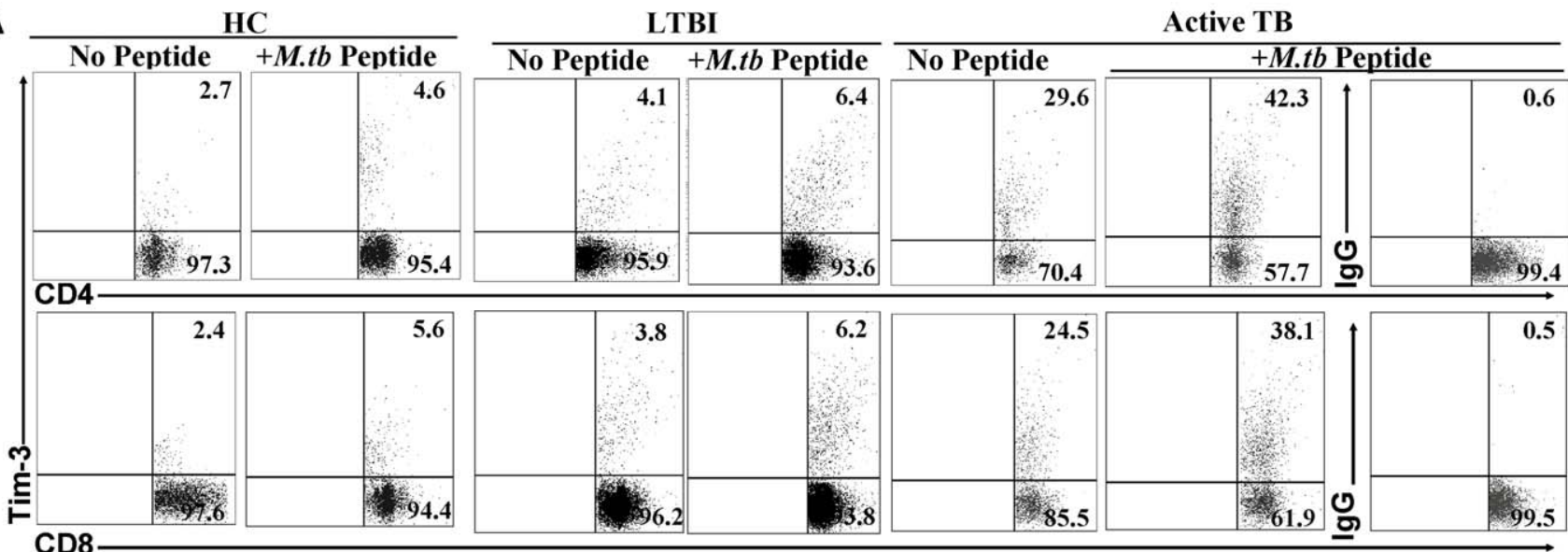

B

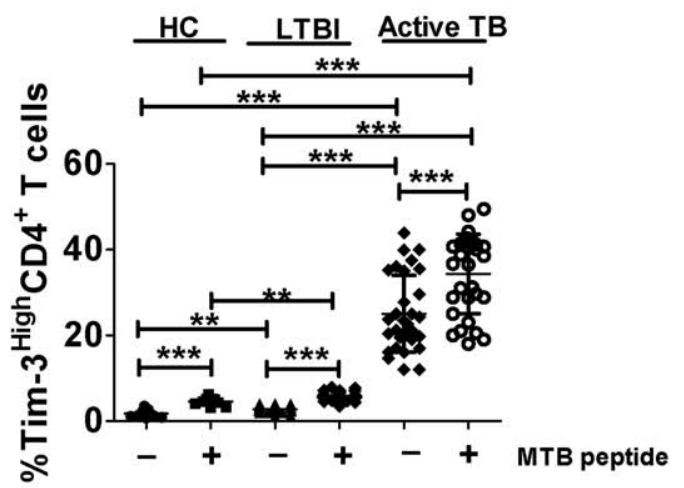

C

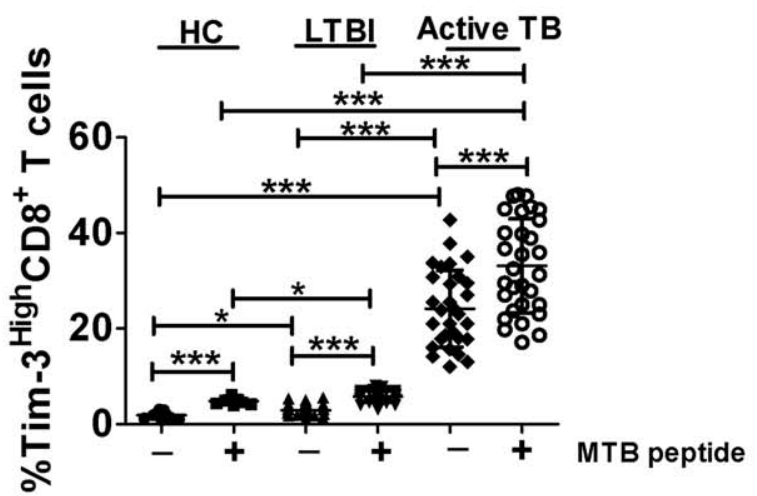

Figure 1. TB infection led to up-regulation of Tim-3 expression and increases in numbers of Tim-3-expressing CD4 ${ }^{+}$and $\mathrm{CDB}^{+} \mathrm{T}^{-}$ cells. PBMC from 30 individuals with untreated active TB disease or 30 individuals with LTBI were stained directly or stimulated ex vivo first with pooled 15aa peptides overlapped by 12 spanning entire Mtb Ag85-b and ESAT-6 (termed Mtb peptide in figures), and then analyzed by polychromatic flow cytometry. (A) Representative flow cytometric dot plots showing Tim-3 expression in a healthy control (HC), a representative individual with untreated active TB disease, or a typical individual with LTBI. No Tim-3 expression was observed when we used isotype matched IgG to stain PBMC (see a representative panel on the right of Figure 1A). Values in the upper right quadrant indicate the percentages of Tim-3-expressing $\mathrm{CD}^{+}$and $\mathrm{CD}^{+} \mathrm{T}$ cells. Data were gated on $\mathrm{CD}^{+} \mathrm{CD}^{+}$and $\mathrm{CD}^{+} \mathrm{CD}^{+}$, respectively. (B) and (C) are bar graph data showing that the percentages (\%) of Tim-3 expression on $\mathrm{CD}^{+}$and $\mathrm{CD} 8^{+}{ }^{\top}$ cells from 30 patients with active TB disease are higher than those from 30 individuals with LTBI and 9 healthy control (HCs). Horizontal bars depict the mean percentage of Mtb-specific Tim-3 expression on $\mathrm{CD} 4^{+}$and $\mathrm{CD} 8^{+} \mathrm{T}$ cells. ${ }^{*} p<0.05$, ${ }^{* *} p<0.01$, **** $p<0.001$.

doi:10.1371/journal.ppat.1002984.g001

Consistently, Tim-3-expressing $\mathrm{CD}^{+}$and $\mathrm{CD}^{+}{ }^{-} \mathrm{T}$ cells expressed low levels of CD27 (Supporting Information, Figure S3A, B, C) and CD62L (Supporting Information, Figure S3D, E, F). In contrast to a lack of CCR7, GD62L, and GD27 expression, however, we found that Tim-3-expressing $\mathrm{CD}^{+}{ }^{+}$and $\mathrm{CD}^{+} \mathrm{T}$ cells expressed high levels of $\mathrm{CD} 127$, another effector memory surrogate marker (Supporting Information, Figure S3G ,H, I). Furthermore, we determined whether Tim-3-expressing $\mathrm{CD}^{+}$ and $\mathrm{CD}^{+}{ }^{+} \mathrm{T}$ cells expressed $\mathrm{CD} 27^{-} \mathrm{CD}_{45 \mathrm{RA}^{-}}$effector memory phenotype by co-staining Tim-3, CD27 and CD45RA on $\mathrm{CD} 3^{+} \mathrm{CD} 4^{+}$and $\mathrm{CD} 3^{+} \mathrm{CD}^{+}{ }^{+} \mathrm{T}$ cells, respectively. We found that Tim-3-expressing $\mathrm{CD}^{+}{ }^{+}$and $\mathrm{CD}^{+}{ }^{+} \mathrm{T}$ cells preferentially displayed CD27 ${ }^{-} \mathrm{CD}^{-} 4 \mathrm{RA}^{-}$effector memory phenotype during active TB disease (Supporting Information, Figure $\mathrm{S} 4 \mathrm{~A}, \mathrm{~B}$, and $\mathrm{C}$ ). Interestingly, we found that most of Tim-3-expressing $\mathrm{CD}^{+}$and $\mathrm{CD}^{+} \mathrm{T}$ cells during LTBI displayed CD27 ${ }^{-} \mathrm{CD} 45 \mathrm{RA}^{-}$effector memory phenotypes (Supporting Information, Figure S4 D, E, and $\mathrm{F}$ and data not shown). These results therefore demonstrated that Tim-3-expressing $\mathrm{CD}^{+}$and $\mathrm{CD}^{+}{ }^{+} \mathrm{T}$ cells in active $\mathrm{TB}$ disease or LTBI preferentially displayed effector memory phenotypes.
Tim- $3^{\text {High }} \mathrm{CD}^{+}$and $\mathrm{CD} 8^{+}$T-cell subsets exhibited greater effector functions for producing IFN- $\gamma$, TNF- $\alpha$, IL-2 and IL22 cytokines than their Tim- $3^{\text {Low }}$ counterparts

Since Mtb-specific $\mathrm{CD}^{+}$and $\mathrm{CD}^{+}{ }^{+} \mathrm{T}$ cells displaying effector memory phenotypes might be able to exert strong anti-mycobacterial effector functions [30,31], we examined whether Mtb-driven Tim-3-expressing $\mathrm{CD}^{+}$and $\mathrm{CD}^{+} \mathrm{T}$ cells exhibited potent effector functions of cytokine production. We used two approaches to determine the relationship between Tim-3 expression and cytokine responses of $\mathrm{CD}^{+}$and $\mathrm{CD}^{+} \mathrm{T}$ cells: (i) PBMC from untreated active TB patients $(\mathrm{n}=9)$ were stimulated $e x$ vivo with Mtb peptides pool, and then stained for Tim-3 and anti-Mtb effector cytokines including IFN- $\gamma$, TNF- $\alpha$, IL-2, and IL-22 and analyzed by polychromatic flow cytometry. This allowed us to evaluate correlation between TB-driven Tim-3 expression and Agstimulated cytokine responses of $\mathrm{CD}^{+}$and $\mathrm{CD}^{+} \mathrm{T}$ cells. (ii) PBMC from the same TB patients $(n=9)$ were directly stained for Tim-3 and the above cytokines without peptide stimulation as we recently described [32] to examine correlation between Tim-3 expression and an ability of Tim-3-expressing $\mathrm{T}$ cells to de novo produce cytokines. The specificity and utility of the direct 
intracellular cytokine staining approach has been validated during Mtb infection of macaques and humans as well as in the control settings $[32,33,34]$.

Interestingly, in the absence of Mtb peptide stimulation, approximately $18-21 \%$ of $\mathrm{Tim}-3{ }^{\mathrm{High}} \mathrm{CD} 4^{+}$T-cell subset from active TB patients were able to produce IFN- $\gamma($ Figure $2 \mathrm{~A}, \mathrm{~B})$, TNF- $\alpha$ (Supporting Information, Figure S5A, B), IL-2(Supporting Information, Figure S5C, D), and IL-22(Supporting Information, Figure S5E, F). In the presence of Mtb peptide stimulation, 30$34 \%$ of $\mathrm{Tim}-3^{\mathrm{High}} \mathrm{CD} 4^{+}$T-cell subset could produce those cytokines(Figure 2A,B, Figure S5C,D,E,F). In contrast, Tim$3^{\text {Low }} \mathrm{CD} 4+\mathrm{T}$-cell subset did not produce appreciable levels of those cytokines regardless of peptide stimulation(Figure 2A,2B, and Supporting Information, Figure S5A,3B, Figure S5C,D, Figure S5E,F). Similarly, high percentages of Tim- $3{ }^{\text {High }}$ CD8+ Tcell subset, but not Tim- $3{ }^{\text {Low }} \mathrm{CD}^{+} \mathrm{T}$-cell subset, from these subjects with active TB disease were able to produce IFN$\gamma^{+}$(Figure 2A,C), TNF- $\alpha^{+}$(Supporting Information, Figure S6A, B), IL- $2^{+}$(Supporting Information, Figure S6C, D) in the presence or absence of ex vivo stimulation with Mtb peptide pool. Interestingly, only $\leq 2.2 \%$ and $\leq 3.5 \%$ cells in Tim $-3{ }^{\text {High }} \mathrm{CD} 4^{+}\left(\right.$or $\left.\mathrm{CD}^{+}\right)$T cells from subjects with LTBI were able to produce cytokines in the absence and presence of $\mathrm{Mtb}$ peptide, respectively (Figure 2D,E,F, Figure S5, and Figure S6), implicating that TB inflammation or disease course contributed to large increase in Tim- $3^{\text {High }} \mathrm{T}$ effector cells actively producing cytokines. Notably, Mtb peptide stimulation led to $\sim 10 \%(\sim 12 \%)$ and $\sim 1 \%(\sim 1.2 \%)$ more increases in cytokine-producing cells in Tim- $3^{\text {High }} \mathrm{CD} 4^{+}$(or $\left.\mathrm{CD}^{+}\right)$T-cell subset in active TB and LTBI, respectively, when compared to the culture without peptide stimulation (Figure 2, Figure S5, Figure S6), These results suggested that the at least some of Tim- $3^{+}$T-cell effector cells were Mtb-specific. Thus, these results demonstrated that consistent with effector phenotypes, Tim $-3^{\text {High }} \mathrm{CD}^{+}$and $\mathrm{CD}^{+}{ }^{+}$T-cell subsets exhibited greater effector functions for producing TB-driven IFN- $\gamma$, TNF- $\alpha$, IL-2 and IL-22 cytokines than their Tim- $3^{\text {Low }}$ counterparts.

\section{Tim- $3^{\text {High }} \mathrm{CD}^{+}$and $\mathrm{CD} 8^{+}$T-cell subsets demonstrated greater effector functions of cytotoxic molecule production and degranulation than their Tim-3 $3^{\text {Low }}$ counterparts}

To further characterize the Tim-3 expression and T-cell effector function, Tim- $3^{\text {High }}$ T-cell subsets were assessed for the ability to produce cytotoxic effector molecuels perforin and granzyme B in comparisons with their Tim- $3^{\text {Low }}$ counterparts. Two above approaches were similarly used in active TB patients $(n=9)$ and individuals with LTBI $(n=9)$. We found that much higher percentages of $\mathrm{Tim}-3^{\mathrm{High}} \mathrm{CD} 4^{+}$and $\mathrm{CD}^{+}$T-cell subsets produced perforin (Figure 3) and granzyme B (Supporting Information, Figure S7) than their Tim- $3^{\text {Low }}$ controls regardless of presence or absence of Mtb peptide stimulation in either active TB disease or LTBI. Similarly, we observed that, compared with those without peptide stimulation, Tim- $3^{\mathrm{High}} \mathrm{CD} 4^{+}$and Tim$3^{\text {High }} \mathrm{CD}^{+} \mathrm{T}$-cell subsets showed stronger T-cell effector function of perforin and granzyme B production upon Mtb peptide stimulation (Figure 3 and Supporting information, Figure S7). To evaluate CTL-related degranulation capacity, Tim- $3^{\text {High }} \mathrm{T}$-cell subsets were assessed for CD107a expression on cell surface, as CD107a, a lysosome-associated membrane glycoprotein, is expressed on cell surface following release of the cytotoxic granule contents, and is usually considered a hallmark for the degranulation capacity of CTL [20]. When compared with Tim-3 $3^{\text {Low }}$ controls, Tim- $3^{\text {High }}$ subsets of $\mathrm{CD}^{+}$and $\mathrm{CD}^{+} \mathrm{T}$ cells from individuals with either active TB disease $(n=9)$ expressed much higher levels of surface CD107a(Supporting Information, Figure S8). Similar higher levels of CD107 expression in Tim- $3^{\text {High }} \mathrm{CD} 4^{+}$ and Tim- $3^{\mathrm{High}} \mathrm{CD}^{+}{ }^{+} \mathrm{T}$-cell subsets were also observed in PBMC from individuals with LTBI (data not shown). Thus, Tim$3^{\text {High }} \mathrm{CD}^{+}$and Tim- $^{+}{ }^{\text {High }} \mathrm{CD}^{+}$T-cell subsets in active TB disease and LTBI demonstrated greater effector functions of production of Mtb-driven cytotoxic molecules and degranulation than their Tim- $3^{\text {Low }}$ counterparts.

\section{Tim-3 silencing by siRNA or interfering with Tim-3 signaling by addition of soluble Tim-3 (s-Tim-3) led to decreases in de novo production of IFN- $\gamma$ and TNF- $\alpha$ by Tim-3-expressing T cells}

To further explore the relationship between Tim-3 expression and effector functions of Tim-3-expressing T cells, we made use of siRNA targeting Tim-3 to knockdown the expression of Tim-3, and evaluated the effects of Tim-3 silencing on production of IFN$\gamma$ and TNF- $\alpha$. siRNA targeting Tim-3(si-Tim-3), but not nontargeting siRNA (si-Control), could significantly knockdown Tim-3, as determined by RT-PCR (Figure 4A) and flow cytometry (Figure 4B, C, F, G). More importantly, silencing of Tim-3 by siRNA in $\mathrm{CD}^{+}$and $\mathrm{CD}^{+} \mathrm{T}$ cells led to significant decreases in production of IFN- $\gamma$ and TNF- $\alpha$ (Figure 4B, D, E, F, H, I), when compared to the controls. These results suggested that Tim-3 expression in active TB was linked to potent IFN- $\gamma$ and TNF- $\alpha$ responses of $\mathrm{CD}^{+}$and $\mathrm{CD}^{+} \mathrm{T}$ cells.

On the other hand, we used Tim-3 ligand competition approach [19] to inhibit Tim-3 signaling pathways and examine the role of Tim-3 signaling in effector function of IFN- $\gamma$ and TNF$\alpha$ production by $\mathrm{CD}^{+}$and $\mathrm{CD} 8^{+} \mathrm{T}$ cells. $\mathrm{PBMC}$ from active TB patients $(n=9)$ were cultured in the presence of low concentration of soluble Tim-3 [termed s-Tim-3, i.e. Tim-3-Ig [7]] under the conditions with or without Mtb peptide pool stimulation. Interestingly, addition of low concentration of s-Tim-3 $(2 \mu \mathrm{g} / \mathrm{ml})$ for interfering with membrane Tim-3-Tim-3 ligand interaction significantly reduced the ability of Tim- $3^{\text {High }}$ T-cell subsets to produce IFN- $\gamma$ and TNF- $\alpha$ cytokines (Figure 5). These results suggested that soluble Tim-3 interfering with membrane Tim-3ligand interaction could impact Tim-3 signaling pathways leading to decreases in effector function of IFN- $\gamma$ and TNF- $\alpha$ production by $\mathrm{Tim}-3^{\mathrm{High}} \mathrm{CD} 4^{+}$and $\mathrm{CD} 8^{+} \mathrm{T}$ cells. However, cytokineproducing $\mathrm{T}$ cells in the culture of s-Tim- 3 plus Mtb peptide were significantly higher than those of s-Tim-3 alone, suggesting again that some of cytokine-producing $\mathrm{Tim}-3^{+} \mathrm{CD} 4^{+}$or $\mathrm{CD}^{+} \mathrm{T}$ cells might be specific for Mtb antigens. The data also supported the notion that Tim-3 expression in active TB helped to drive stronger anti-microbial effector functions of $\mathrm{CD} 4^{+}$and $\mathrm{CD}^{+} \mathrm{T}$ cells.

\section{Stimulation of Tim-3 signaling pathways by Ab cross- linking of membrane Tim-3 augmented effector function of IFN- $\gamma$ production by $\mathrm{CD}^{+}$and $\mathrm{CD}^{+}{ }^{+}$cells}

We then examined whether enhancing of Tim-3 signaling could augment effector function of IFN $-\gamma$ production by $\mathrm{CD} 4^{+}$ and $\mathrm{CD}^{+} \mathrm{T}$ cells. Because anti-Tim- $3 \mathrm{mAb}$ could cross-link membrane Tim-3 and enhance Tim-3 signaling [35,36], we used this approach to enhance Tim-3 signaling. PBMC from active TB patients $(n=9)$ were incubated with anti-Tim- $3 \mathrm{mAb}$ or isotype control $\mathrm{Ab}$ in presence or absence of Mtb peptide pool, and then assessed for potential effects of enhancing Tim-3 signal on IFN- $\gamma$ production by $\mathrm{CD}^{+}$and $\mathrm{CD}^{+}{ }^{+} \mathrm{T}$ cells. Interestingly, addition of anti-Tim- $3 \mathrm{mAb}$, but not control $\mathrm{Ab}$, to $\mathrm{PBMC}$ cultures resulted in significant increases in effector 
A

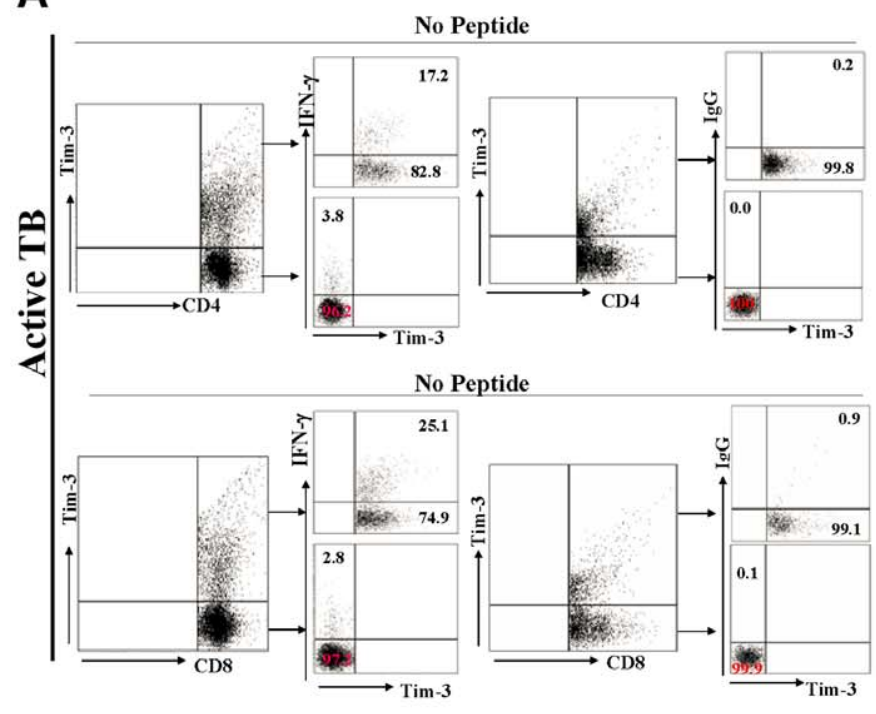

D

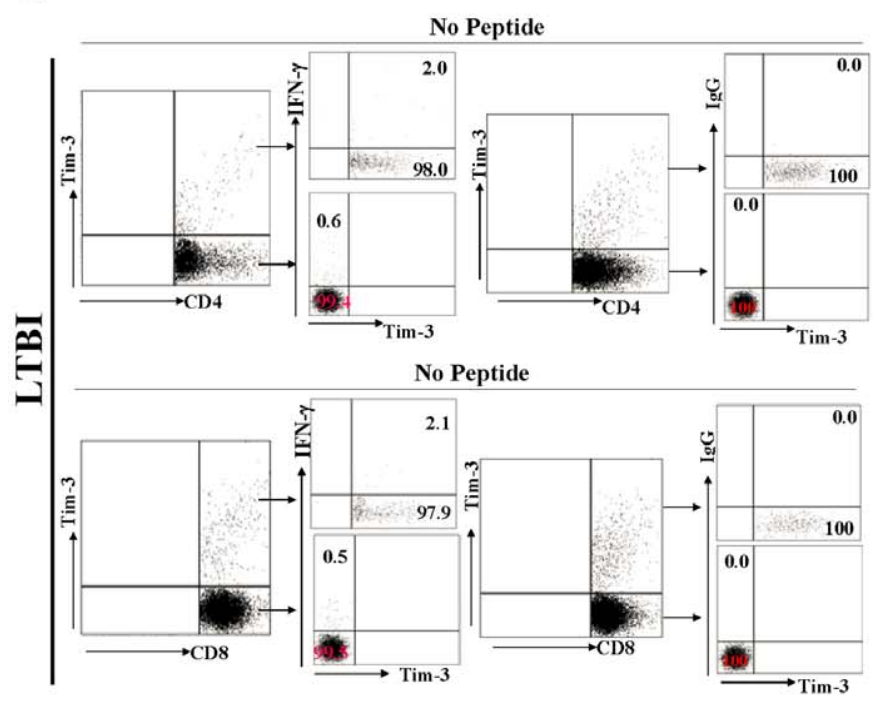

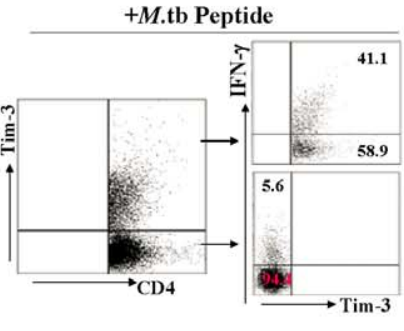

$+M$. tb Peptide
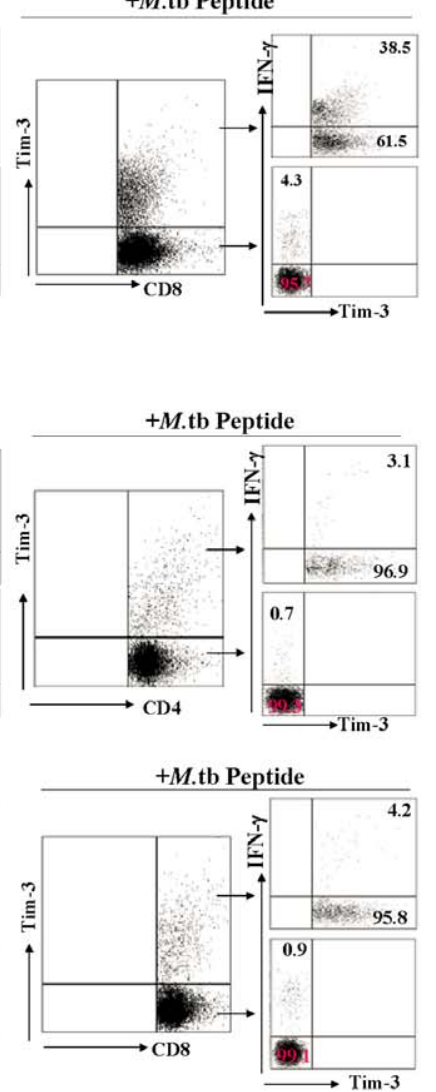

B

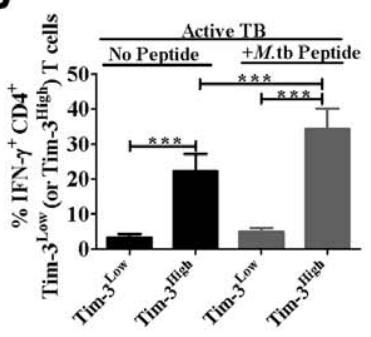

C

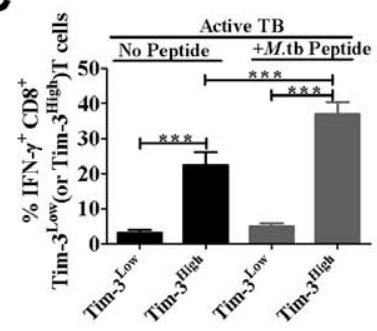

E

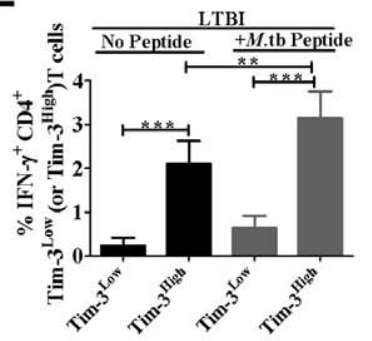

$\mathbf{F}$

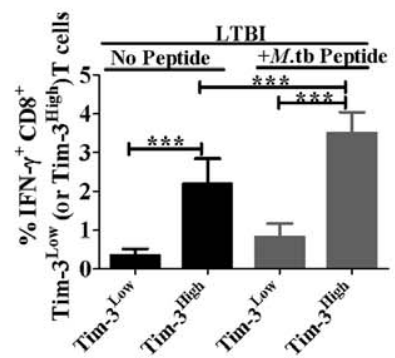

Figure 2. Tim-3 ${ }^{\text {High }} \mathrm{CD4}^{+}$and $\mathrm{CD8}^{+}$T-cell subsets showed greater effector functions for producing Mtb-specific IFN- $\gamma$ and other cytokines (see Supporting Information, Figure S5, Figure S6) than their Tim-3 ${ }^{\text {Low }}$ counterparts. PBMC derived from individuals with active TB disease $(n=9)$ or with LTBI $(n=9)$ were cultured ex vivo in presence or absence of pooled Ag85-b/ESAT- 6 peptides, stained for fluorochrome-conjugated mAbs and analyzed by polychromatic flow cytometry. To examine the association between the IFN- $\gamma$ response and Tim-3 expression, we used a two-tiered gating system for analyzing IFN- $\gamma$ response by Tim-3-expressing T cells (Tim- $3^{\text {High }}$ ) and Tim-3-negative cells $\left(\mathrm{Tim}^{\mathrm{Tim}}\right.$ $3^{\text {Low }}$ ) subpopulations. (A) shows representative flow cytometric dot plots derived from an untreated active TB patient, indicating percentages of IFN$\gamma$-producing cells in Tim-3 $3^{\text {High }} \mathrm{CD}^{+}$(or CD8 ${ }^{+}$) T-cell subset versus Tim- $-3^{\text {Low }} \mathrm{CD}^{+}$(or $\mathrm{CD} 8^{+}$) T-cell subset under the conditions with or without ex vivo stimulation with pooled Ag85B/ESAT-6 peptide. No significant intracellular staining of IFN- $\gamma$ and other cytokines was seen when using isotype Ig control (see a representative panel in Figure 2A). (D) Similar flow cytometric dot plots show numbers of IFN- $\gamma$-producing cells in Tim-3 $3^{\text {High }} \mathrm{CD} 4^{+}$(or $\mathrm{CD}^{+}$) T cells versus Tim- $3^{\mathrm{Low}} \mathrm{CD}^{+}$(or $\mathrm{CD} 8^{+}$) T cells in an individual with LTBI. (B) shows bar graph data from individuals with active TB disease $(\mathrm{n}=9$ ) and demonstrates that percentages of IFN- $\gamma^{+}$T cells within Tim- $3^{\text {High }} \mathrm{CD}^{+}{ }^{+} \mathrm{T}$-cell subsets are much greater than those within Tim- $3^{\text {Low }} \mathrm{CD} 4^{+} \mathrm{T}$ cell subsets. (C) is similar to (B), except that data are IFN- $\gamma^{+}$T cells within Tim- $-3^{\text {High }} \mathrm{CD} 8^{+}$T-cell subsets. (E) are bar graph data from individuals with LTBI $(n=9)$ showing that percentages of IFN- $\gamma^{+} T$ cells within Tim- $3^{\text {High }} \mathrm{CD}^{+}$T-cell subsets are much greater than those within Tim- $3^{\text {Low }} \mathrm{CD} 4^{+} \mathrm{T}$ cell subset. (F) is similar to (E), except that data are IFN- $\gamma^{+}$T cells within Tim- $3^{\text {High }}$ (or Tim- $3^{\text {Low }}$ )CD8 ${ }^{+}$T-cell subsets. Shown are data from at least three independent experiments. ${ }^{* *} p<0.01,{ }^{* * *} p<0.001$. Error bars represent SD. Note that frequencies of cytokine-producing cells are expressed within $\mathrm{Tim}-3^{+}$or Tim- $3^{-}$IFN- $\gamma^{+} \mathrm{CD} 4^{+}$or $\mathrm{CD} 8^{+}$T subsets, not total $\mathrm{CD} 4^{+}$or $\mathrm{CD} 8^{+} \mathrm{T}$-cell population. Numbers of IFN- $\gamma$-producing cells within peptide-stimulated and unstimulated Tim $-3^{+} \mathrm{CD}^{+}$(or $\left.\mathrm{CD} 8^{+}\right)$T-cell subsets in active TB patients are significantly greater than those in healthy subjects with LTBI $(p<0.001)$. doi:10.1371/journal.ppat.1002984.g002

function of IFN- $\gamma$ production by Tim- $3^{\mathrm{High}} \mathrm{CD} 4^{+}$and $\mathrm{CD} 8^{+} \mathrm{T}-$ cell subsets (Supporting Information, Figure S9). Similar enhancement of T-cell effector functions by cross-linking Tim3 on T-cell surface was also observed in PBMC of HCs and subjects with LTBI (data not shown). These results provided additional support for the hypothesis that Tim-3 signaling in $\mathrm{CD}^{+}$and $\mathrm{CD}^{+} \mathrm{T}$ cells helped to promote effector function of Thl cytokine production. 
A
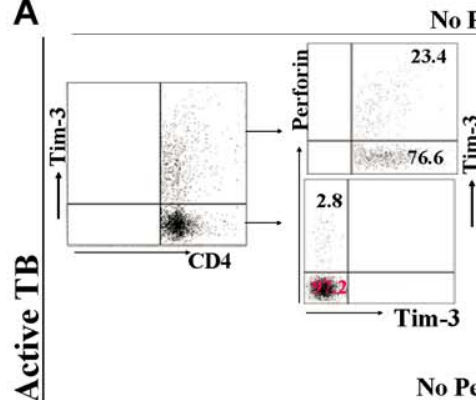

o Peptide
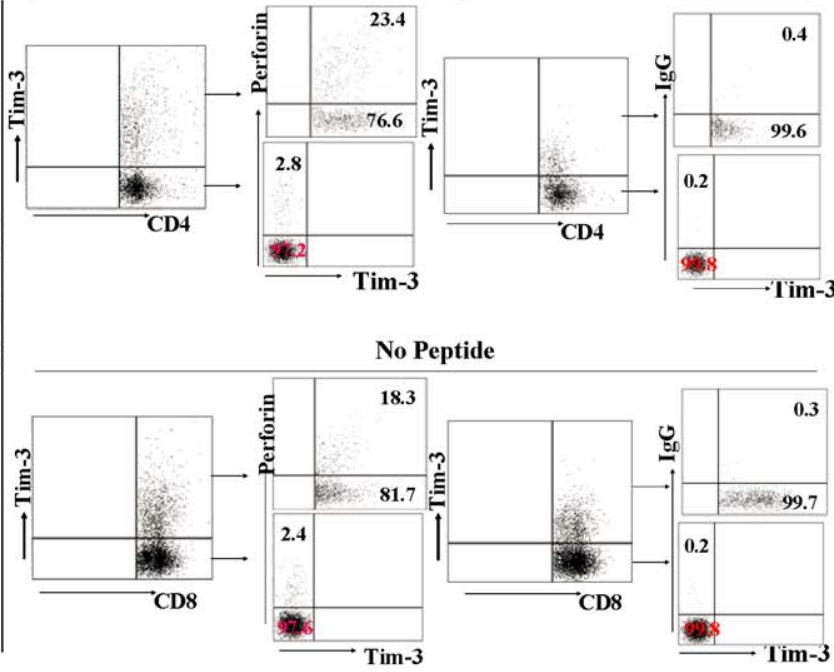

o Peptide

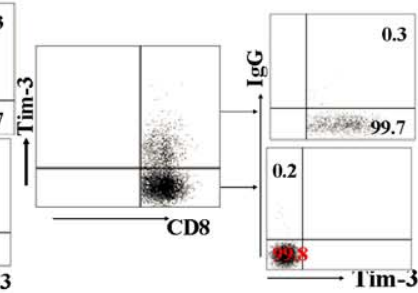

D
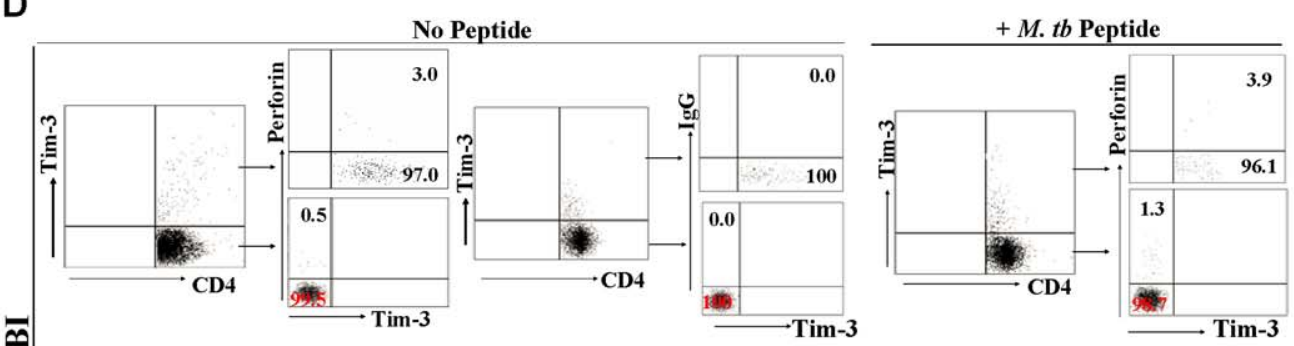

No Peptide
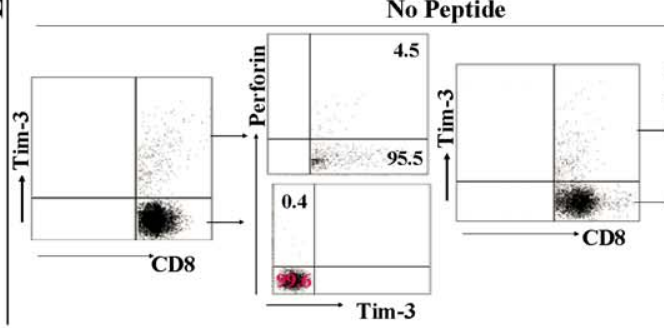
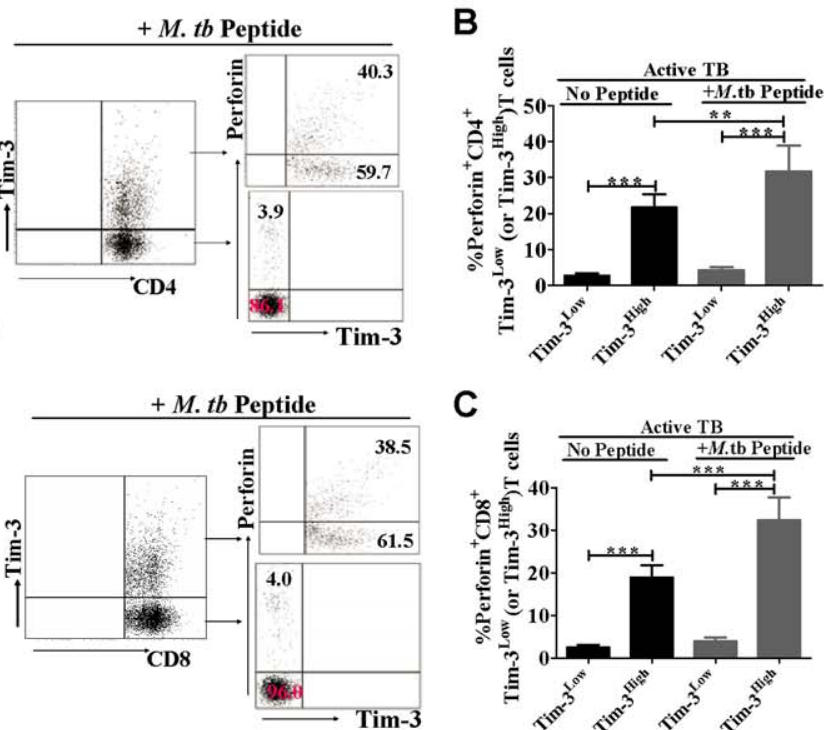

C

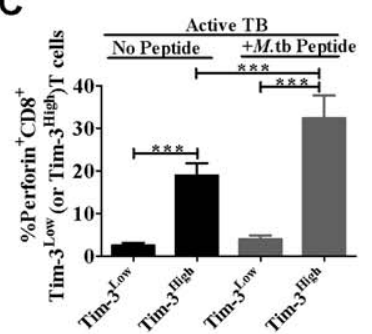

E

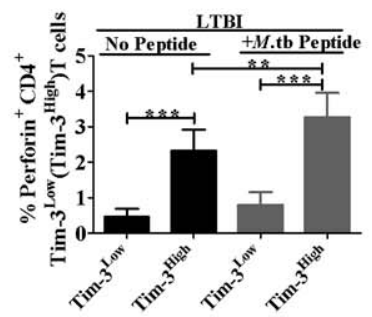

$\mathbf{F}$

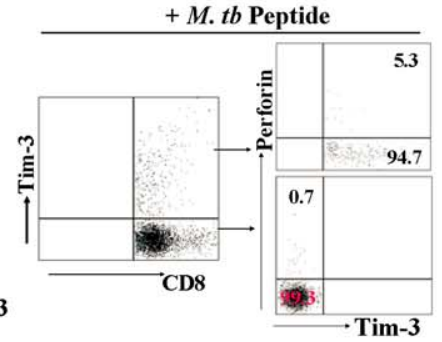

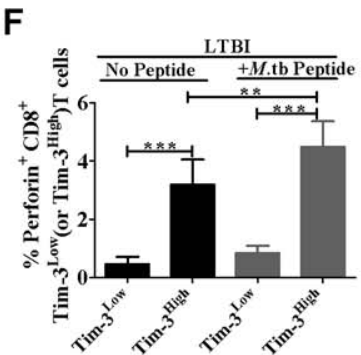

Figure 3. Tim- $3^{\text {High }} \mathrm{CD4}^{+}$and $\mathrm{CD8}^{+} \mathrm{T}^{-c e l l}$ subsets also had greater effector functions of cytotoxic molecule production than their Tim- $3^{\text {Low }}$ counterparts. PBMC from individuals with active TB disease $(n=9)$ or with LTBI $(n=9)$ were cultured in presence or absence of pooled Ag85-b/ESAT- 6 peptides, stained with fluorochrome-conjugated mAbs, and analyzed by polychromatic flow cytometry. (A) shows representative flow cytometric dot plots derived from an untreated active TB patient, indicating percentages of perforin-producing cells in Tim- $3^{\mathrm{High}} \mathrm{CD} 4^{+}$(or CD $8^{+}$) T-cell subset versus Tim- $3^{\text {Low }} \mathrm{CD}^{+}$(or CD8 ${ }^{+}$) T-cell subset under the conditions with or without ex vivo stimulation with pooled Ag85B/ESAT-6 peptide. (D) Similar flow cytometric dot plots show numbers of perforin-producing cells in Tim $-3^{\text {High }} \mathrm{CD}^{+}$(or $\mathrm{CD} 8^{+}$) T cells versus Tim- $3^{\mathrm{Low}} \mathrm{CD} 4^{+}$(or CD8 ${ }^{+}$) T cells in an individual with LTBI. (B) shows bar graph data from individuals with active TB disease $(n=9)$ and demonstrates that percentages of perforin ${ }^{+} T$ cells within Tim- $3^{\text {High }} \mathrm{CD} 4{ }^{+}$T-cell subsets are much greater than those within Tim- $-3^{\text {Low }}{ }^{2}{ }^{+}{ }^{+}$T cell subsets. $(C)$ is similar to $(B)$, except that data are perforin ${ }^{+}$ T cells within Tim- $3^{\text {High }}$ (or Tim- $3^{\text {Low }}$ CD $8^{+}$T-cell subsets. $(E)$ are bar graph data from individuals with LTBI $(n=9)$ showing that percentages of perforin ${ }^{+} \mathrm{T}$ cells within Tim- $3^{\text {High }} \mathrm{CD} 4^{+} \mathrm{T}$-cell subsets are much greater than those within Tim- $3^{\text {Low }}{ }^{C D} 4^{+} \mathrm{T}$ cell subsets. (F) is similar to (E), except that data are perforin ${ }^{+} \mathrm{T}$ cells within Tim- $3^{\mathrm{High}}$ (or Tim- $\left.3^{\mathrm{Low}}\right) \mathrm{CD} 8^{+} \mathrm{T}$-cell subsets. Shown are data from at least three independent experiments. ${ }^{* *} p<0.01$, ${ }^{* * *} p<0.001$. Error bars represent SD. Numbers of perforin-producing cells within peptide-stimulated and unstimulated Tim- $3^{+} \mathrm{CD} 4^{+}\left(\right.$or $\left.\mathrm{CD} 8^{+}\right) \mathrm{T}-\mathrm{cell}$ subsets in active TB patients are significantly greater than those in healthy subjects with LTBI $(p<0.001)$.

doi:10.1371/journal.ppat.1002984.g003

Tim-3 $3^{\text {High }} \mathrm{T}$ cells in active TB patients mounted stronger anti-Mtb effector function limiting intracellular Mtb replication in macrophages (MФs)

While Tim-3 expression could regulate immune status of MФs [35], our results implicated that Tim-3 expression enhanced Tcell effector functions for producing anti-microbial cytokines and cytotoxic molecules. Because it has also been suggested that IL-1 $\beta$ might contribute to the Tim-3-mediated inhibition of intracellu- lar Mtb growth [37], we then asked whether Tim-3-expressing $\mathrm{T}$ cells could limit intracellular Mtb replication in MФs, and whether IL- $1 \beta$ played a role in Tim- $3^{+} \mathrm{T}$ cell-induced anti-Mtb effector function. To address these questions, Tim-3-expressing $\mathrm{CD}^{+}{ }^{+} \mathrm{T}$ cells $\left(\mathrm{Tim}-3^{+} \mathrm{CD} 3^{+} \mathrm{T}\right.$ cells) were isolated from PBMCs of active TB patients $(\mathrm{n}=9)$ using magnetic beads techniques, as we described [34], and co-cultured with Mtb-infected autologous $\mathrm{M} \Phi_{\mathrm{s}}$ in presence or absence of anti-IL-1 $\beta \mathrm{Ab}$ or isotype control 
A

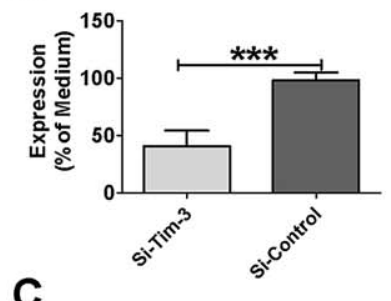

C

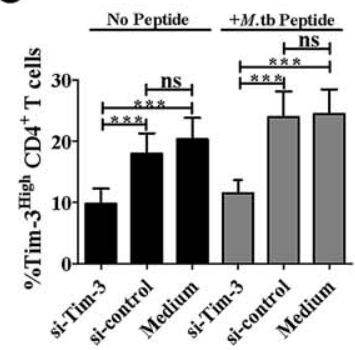

D

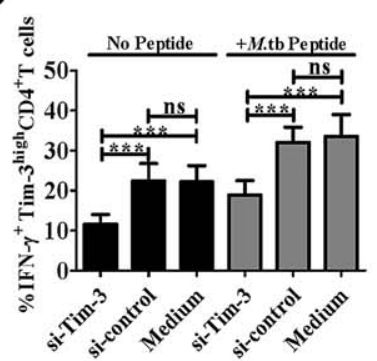

E

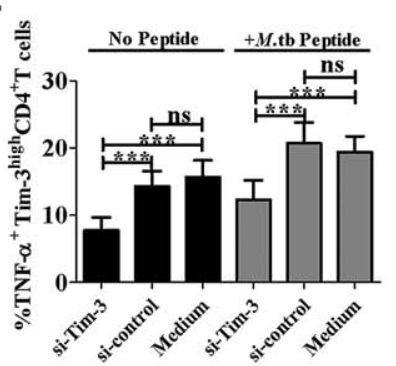

B

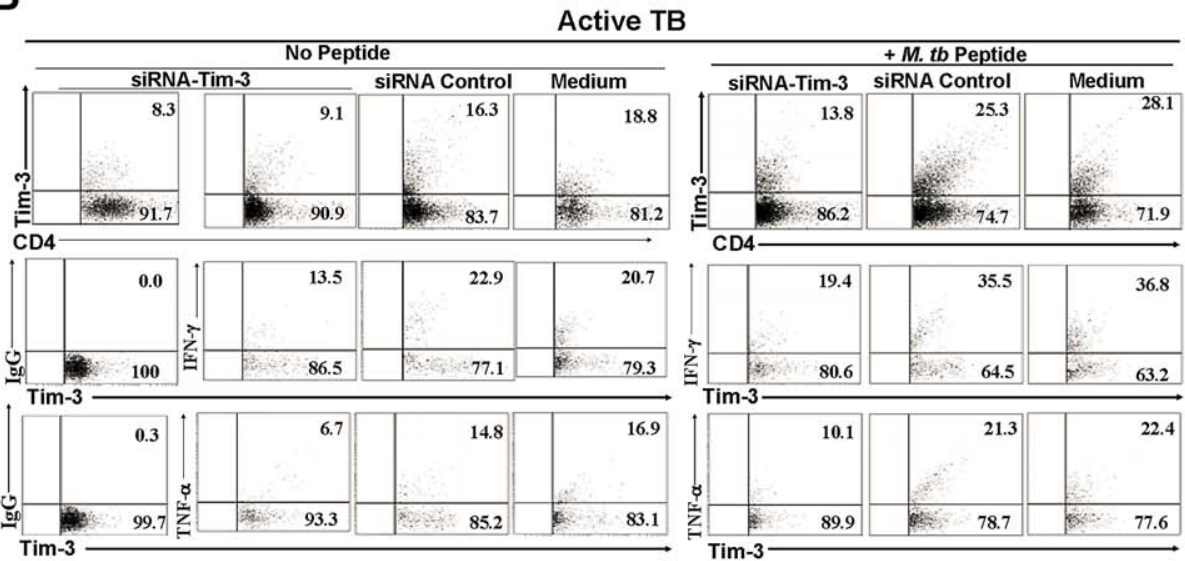

F
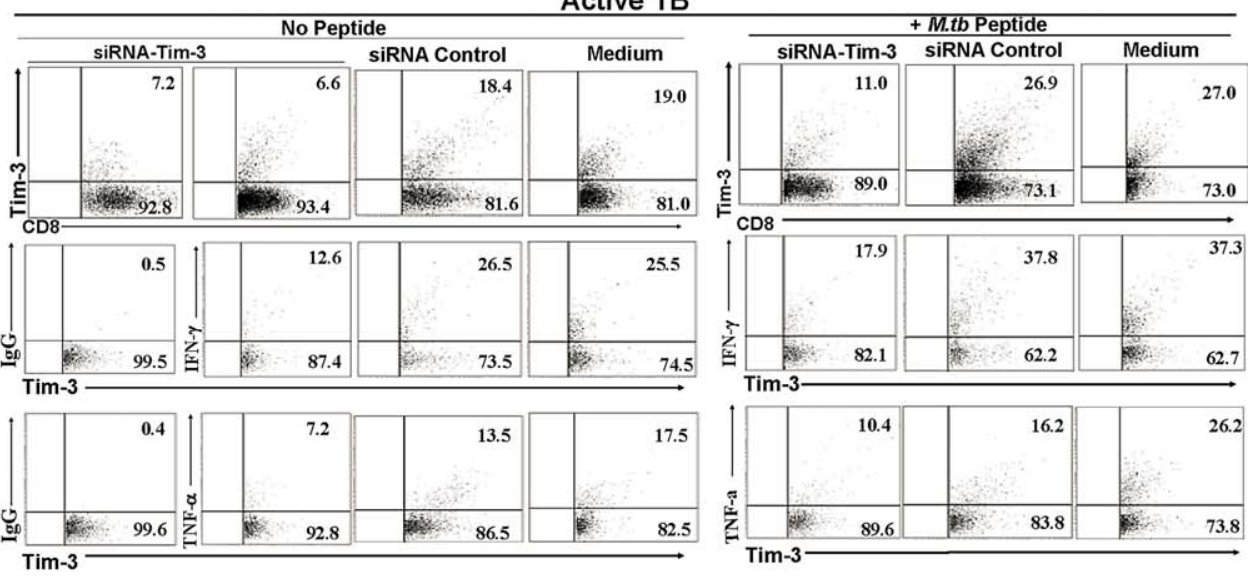

G

H

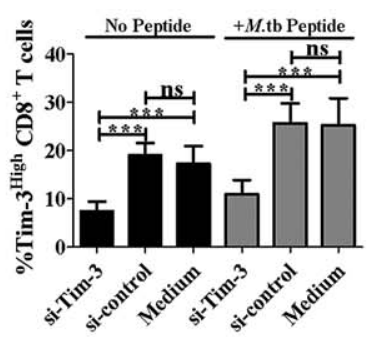

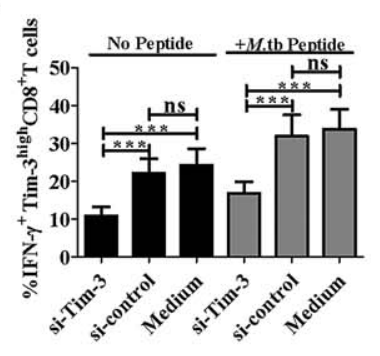

I

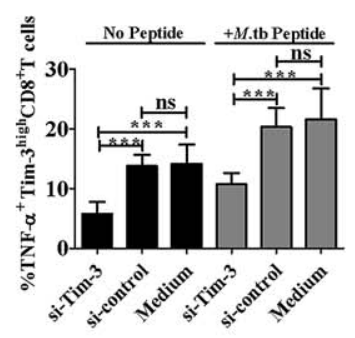

Figure 4. Tim-3 knockdown by siRNA led to decreases in de novo production of IFN- $\gamma$ and TNF- $\alpha$ by CD4 ${ }^{+}$and CD8 $^{+}$T cells. PBMC isolated from untreated active TB patients $(n=9)$ were transiently transfected with Tim-3-targeting (si-Tim-3) or control siRNA (si-control). Cells were then stimulated with or without pooled Ag85-b/ESAT- 6 peptides for 6 days, stained by ICS with fluorochrome-conjugated mAbs and evaluated for the effects of Tim-3 silencing on T-cell effector functions using polychromatic flow cytometry. (A) Real-time PCR analysis of the expression of Tim-3 in PBMC from Mtb-infected subjects $(n=9)$ at $48 \mathrm{hrs}$ after transient transfection of Tim-3-targeted siRNA(si-Tim-3) and non-targeted siRNA(si-control), with data presented as values relative to expression in PBMC treated with Lipofectamine medium. (B) Typical flow cytometric dot plots and (C) summary bar graphic data show that Tim-3-specific siRNA (si-Tim-3), but not non-targeted siRNA(si-control) or Lipofectamine medium, specifically reduces the de novo or Mtb-driven expression of Tim-3 in $\mathrm{CD}^{+}$and $\mathrm{CD} 8^{+} \mathrm{T}$ cells. Values in upper right quadrant of flow cytometric dot plots indicate the percentages of Tim- $3^{\text {High }}$ cells. (B) Flow cytometric dot plots and (D, E) summary bar graphic data show that Tim-3-targeted siRNA (si-Tim-3), but not non-targeted siRNA(si-control) or Lipofectamine medium, significantly reduces the percentages of IFN- $\gamma$ - and TNF- $\alpha$-expressing T cells in Tim$3^{\text {High }} \mathrm{CD}^{+}{ }^{+} \mathrm{CD} 4^{+} \mathrm{T}$ cells. Dot plots in (B) were gated on Tim $-3^{\text {High }} \mathrm{CD}^{+} \mathrm{CD} 4^{+} \mathrm{T}$ cells. $(\mathrm{F}),(\mathrm{G})$, (H), and (I) show that similar results in Tim- $3^{\text {High }} \mathrm{CD} 3^{+} \mathrm{CD} 8^{+} \mathrm{T}$ cells. Dot plots in (F) were gated on Tim- $3^{\text {High }} \mathrm{CD}^{+} \mathrm{CD}^{+} \mathrm{T}$ cells. Values in each of flow cytometric dot plots are percentages of IFN- $\gamma-$ or TNF- $\alpha-$ expressing T cells in Tim $-3^{H i g h}{ }^{H} 3^{+} C D 4$ (or CD8) ${ }^{+} T$ cells. Data are from at least three independent experiments. Error bars represent SD. ${ }^{* * *} p<0.001$, NS, no statistical significance.

doi:10.1371/journal.ppat.1002984.g004

Ab. The co-cultured cells were then lysed, and lysate was measured for Mtb CFU counts on plates as we previously described [34]. Tim- $3^{-} \mathrm{CD}^{+} \mathrm{T}$ cells served as control.
Interestingly, Tim-3-expressing $\mathrm{T}$ cells more apparently limited intracellular Mtb growth than Tim $-3^{-} \mathrm{CD} 3^{+} \mathrm{T}$ cells (Figure 6). Furthermore, treatment with anti-IL-1 $\beta \mathrm{Ab}$, but not isotype 
A

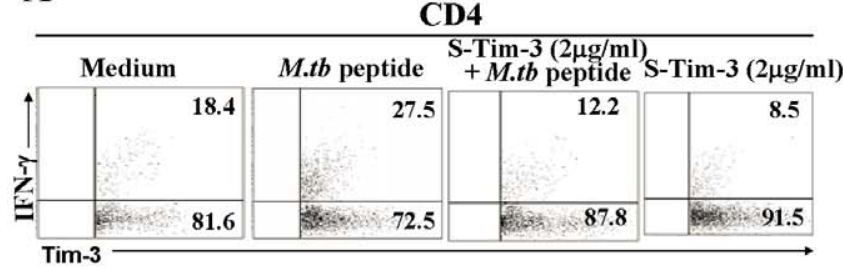

C

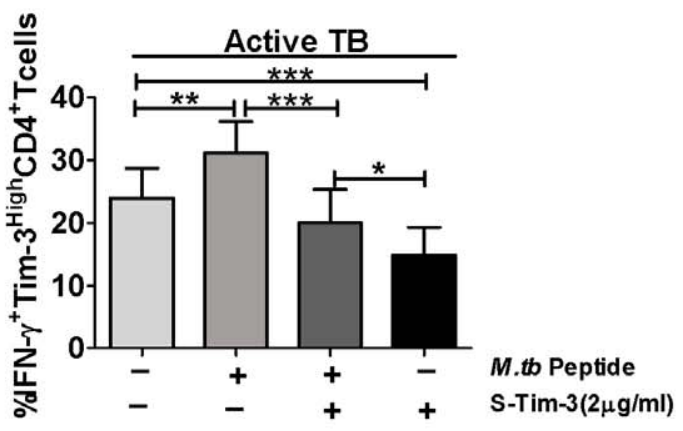

E

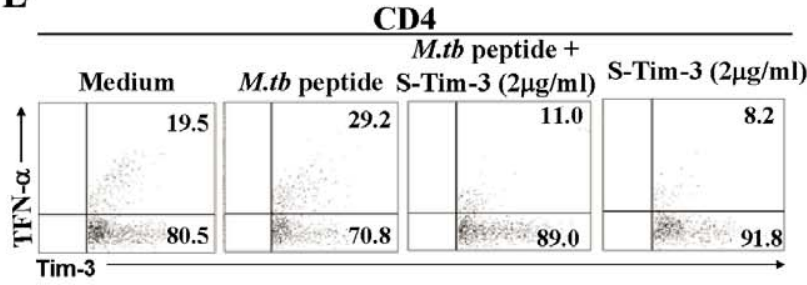

G

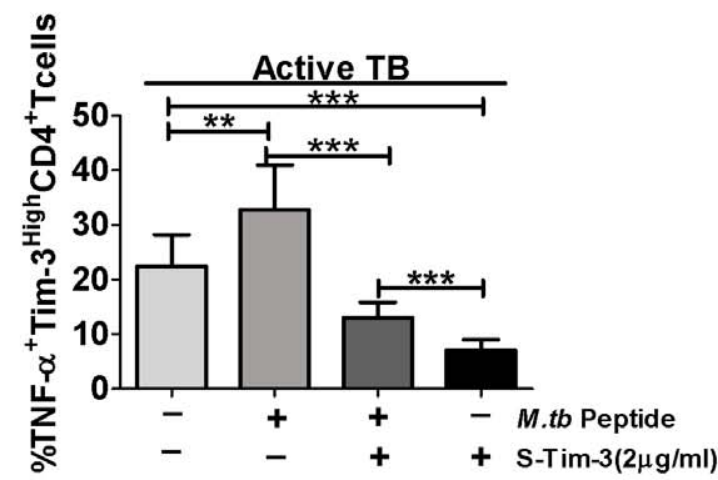

B

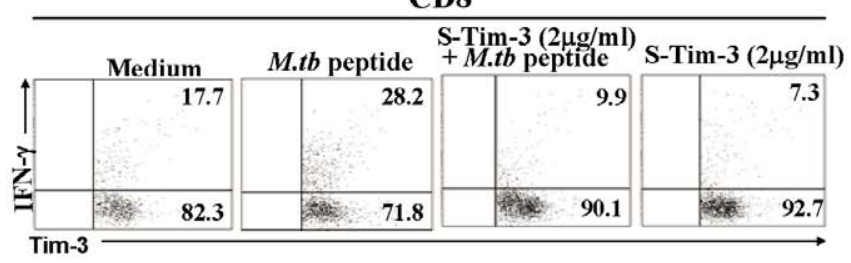

D

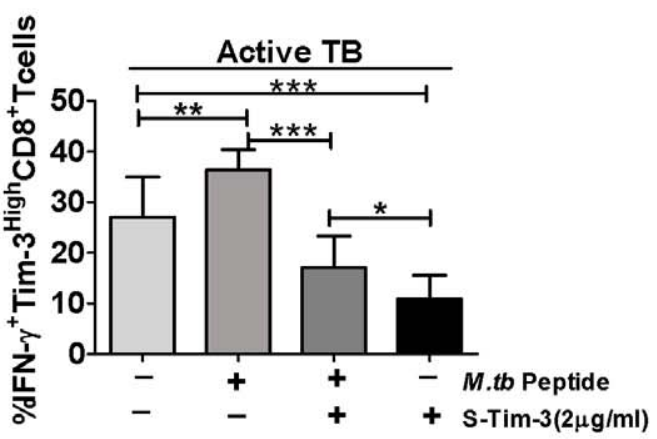

F

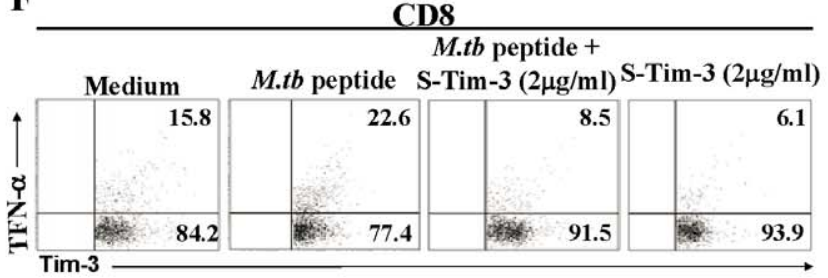

H

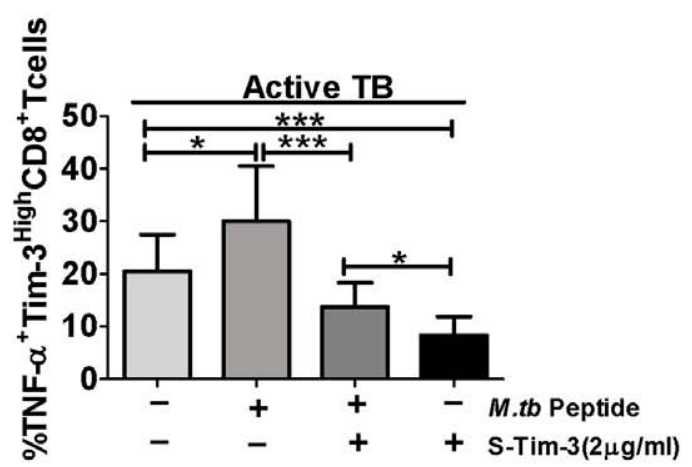

Figure 5. Adding a low concentration of soluble Tim-3 (s-Tim-3) to PBMC cultures reduced effector functions of IFN- $\gamma$ and TNF- $\alpha$ production by Tim-3-expressing $\mathrm{CD4}^{+}$and $\mathrm{CD8}^{+} \mathbf{T}$ cells. PBMC derived from untreated active TB patients $(n=9)$ were incubated with soluble form of Tim-3 (s-Tim-3) in a concentration of $2 \mu \mathrm{g} / \mathrm{ml}$ in presence or absence of pooled Mtb Ag85-b/ESAT- 6 peptides for 6 days. Cells were then stained using the ICS protocol, and analyzed by flow cytometry. (A) and (E) show representative flow cytometric data demonstrating the effects of Tim-3 ligand competition on Mtb-driven IFN- $\gamma$ and TNF- $\alpha$ responses of Tim- $3^{\text {High }} \mathrm{CD}^{+} \mathrm{T}$ cells. (C) and (G) show bar graphic data demonstrating that ligand competition by adding $2 \mu \mathrm{g} / \mathrm{ml}$ of soluble Tim-3 (s-Tim-3) significantly inhibits Mtb-driven IFN- $\gamma$ and TNF- $\alpha$ production by CD4 ${ }^{+}$T cells. (B), (D), $(\mathrm{F})$, and $(\mathrm{H})$ show similar results were also observed in Tim $-3^{\text {High }} \mathrm{CD}^{+} \mathrm{T}$ cells. Data are from at least two independent experiments. Error bars represent SD. ${ }^{*} p<0.05,{ }^{* *} p<0.01{ }^{* * *} p<0.001$.

doi:10.1371/journal.ppat.1002984.g005

control $\mathrm{Ab}$, could reverse the $\mathrm{Tim}-3^{+} \mathrm{CD} 3^{+} \mathrm{T}$ cell-mediated inhibition of intracellular Mtb growth, suggesting that IL-1 $\beta$ might contribute to the limitation of intracellular Mtb growth mediated by $\mathrm{Tim}-3^{+} \mathrm{CD}^{+} \mathrm{T}$ cells. Thus, Tim-3-expressing $\mathrm{T}$ cells in active TB patients appeared to mount stronger anti-Mtb effector function limiting intracellular Mtb replication in cultured MФs.
Tim- $3^{\text {High }} \mathrm{CD}^{+}$and $\mathrm{CD}^{+}$T-cell subsets in active TB patients expressed higher levels of phosphorylated signaling molecules p38, stat3, stat5, and Erk1/2

Given that $\mathrm{Tim}-3^{\mathrm{High}} \mathrm{CD} 4^{+}$and $\mathrm{CD}^{+}{ }^{+} \mathrm{T}$-cell subsets exhibited greater effector functions of producing Thl cytokines/cytotoxic molecules and limiting intracellular Mtb growth, we sought to determine a potential signaling mecha- 


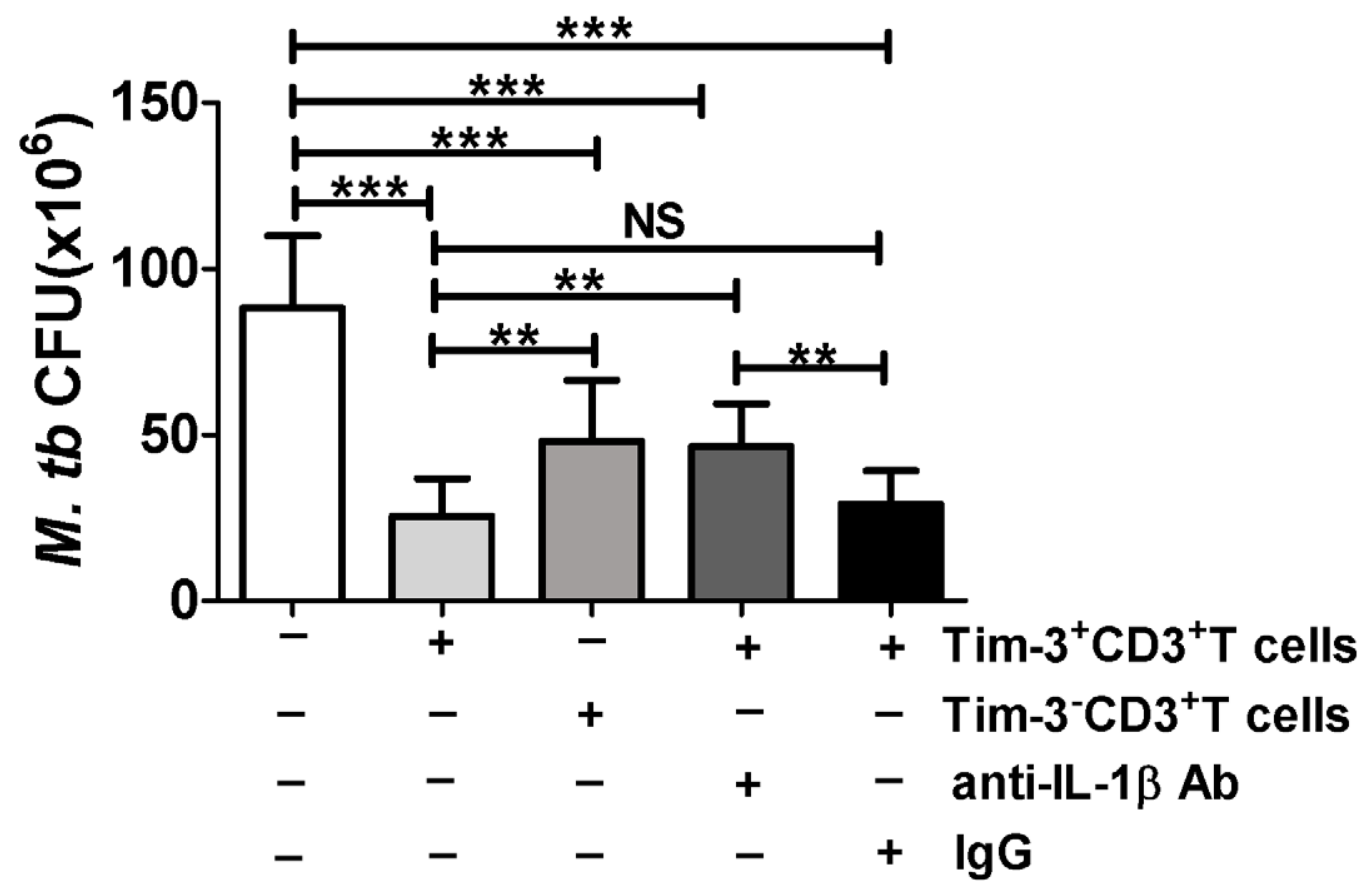

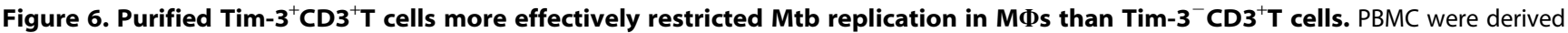
from untreated active TB patients $(n=9)$. Monocytes-derived MФs were infected with Mtb overnight, and extracellular Mtb were then removed by extensive PBS wash. Autologous Tim $-3^{+} \mathrm{CD}^{+} \mathrm{T}$ cells and Tim $-3^{-} \mathrm{CD}^{+} \mathrm{T}$ cells were purified by magnetic beads and co-cultured with Mtb-infected MФs for 4 days in presence or absence of anti-IL-1 $\beta$ Ab and isotype control IgG. Cultured cells containing Mtb-infected cells were then lysed, and Mtb CFUs were examined (see details in Materials and Methods). CFU numbers were expressed as per $10^{6} \mathrm{M} \Phi$ s. Data are from at least three independent experiments. Error bars represent SD. ${ }^{* *} p<0.001,{ }^{* *} p<0.01$, NS, no statistical significance.

doi:10.1371/journal.ppat.1002984.g006

nism underlying the Tim-3-associated enhancements. Since appropriate activation signaling is usually required for efficient T-cell effector functions in responses to Mtb infection [38], we hypothesized that greater $\mathrm{T}$ effector functions of Tim- $3^{\text {High }}$ $\mathrm{CD}^{+}$and $\mathrm{CD}^{+}{ }^{+} \mathrm{T}$-cell subsets during Mtb infection might be driven by stronger intracellular signaling and activation. To test this hypothesis, we measured the phosphorylation of signaling molecules $\mathrm{p} 38$, stat 3 , stat 5 , and Erk $1 / 2$ in Tim- $3^{\text {High }}$ $\mathrm{CD}^{+}$and $\mathrm{CD}^{+} \mathrm{T}$-cell subsets from active $\mathrm{TB}$ patients in comparisons with Tim- $3^{\text {Low }}$ control subsets. Thus, PBMC from 9 active TB patients were directly stained without ex vivo Mtb peptide stimulation or stimulated ex vivo with Mtb peptide pool, and the phosphorylated (termed P- for simplicity) p38, stat3, stat5, and Erk1/2 were immunologically stained and quantitated by flow cytometry. We found that expression levels of $\mathrm{P}-$ p38, P-stat3, P-stat5, and P-Erk1/2 in Tim- $3^{\text {High }} \mathrm{CD} 4^{+}$and $\mathrm{CD}^{+} \mathrm{T}$-cell subsets were much higher than those in Tim- $3^{\text {Low }}$ control subsets in cultures with or without Mtb peptide antigen stimulation (Figure 7). The finding that unstimulated Tim $-3^{+}$, but not Tim- $3^{-}$, T cells had higher levels of phosphorilated signal molecules was consistent with the ability of $\mathrm{Tim}-3^{+} \mathrm{T}$ cells to de novo produce cytokines(Figure 2,3, Figure S5,S6) and to exert anti-Mtb effector function(Figure 6). Furthermore, expression levels of P-p38, P-stat5, and P-Erk1/2 were much higher than that of $\mathrm{P}$-stat 3 within Tim- $3^{\text {High }} \mathrm{CD} 4^{+}$and $\mathrm{CD} 8^{+}$ T-cell subsets (Figure 7). Thus, Tim- $3^{\text {High }} \mathrm{CD} 4^{+}$and $\mathrm{CD}^{+}{ }^{+} \mathrm{T}$ cell subsets in active TB patients expressed higher levels of phosphorylated signaling molecules, suggesting that Tim-3associated increases in $\mathrm{T}$ effector functions may involve activation signaling molecules p38, stat5, and Erk1/2 rather than stat3.

\section{Discussion}

In the current study, we have made several interesting observations regarding Mtb infection-induced increases in Tim3-expressing $\mathrm{CD}^{+}{ }^{+}$and $\mathrm{CD}^{+}{ }^{+} \mathrm{T}$-cell subsets, Tim-3-related broad effector functions for producing Th1/Th22/cytotoxic cytokines and limiting intracellular Mtb growth, and potential mechanisms underlying Tim-3 signaling-driven enhancements of effector functions. These findings are considered novel as there are no reports, to our knowledge, for in-depth studies of Tim-3-driven Tcell immune responses in active human TB.

Interestingly, active TB patients exhibit up-regulation of Tim-3 expression and increases in Tim-3-expressing $\mathrm{CD} 4^{+}$and $\mathrm{CD}^{+} \mathrm{T}$ cells, and Tim-3-expressing $\mathrm{T}$ cells predominantly displayed a polarized effector memory phenotype (lack of expression of CCR7, CD62L, or CD27) [31]. Consistently, Tim-3-expressing Mtbspecific $\mathrm{CD}^{+}{ }^{+}$and $\mathrm{CD}^{+}{ }^{+} \mathrm{T}$ cells in active $\mathrm{TB}$ patients also express high levels of another effector memory surrogate marker CD127 (IL-7 Receptor $\alpha$ ) [39]. It is likely that effector memory phenotypes $\left(\mathrm{CD} 127^{+}\right.$but $\mathrm{CCR}^{-}, \mathrm{CD}^{-} 2 \mathrm{~L}^{-}$and $\mathrm{CD} 27^{-}$) not only favor Tim3-expressing $\mathrm{T}$ cells for mounting effector functions of antimicrobial cytokine production and cytotoxicity but also facilitate these effector $\mathrm{T}$ cells trafficking to Mtb infection sites or inflamed lung tissues $[31,39,40]$. It is noteworthy that the predominant effector memory phenotypes of Mtb-driven Tim-3-expressing $\mathrm{CD}^{+}$and $\mathrm{CD}^{+}{ }^{+} \mathrm{T}$ cells in active $\mathrm{TB}$ patients differ from virusinduced central memory phenotypic Tim-3-expressing $\mathrm{CD}^{+} \mathrm{T}$ cells in HCV- or HIV-1-infected humans [16,19,20]. It has been reported that Tim-3-expressing $\mathrm{CD}^{+} \mathrm{T}$ cells during $\mathrm{HCV}$ or HIV-1 infection display either dominant $\mathrm{CCR} 7^{+}$central memory or $\mathrm{CCR}^{+}$and/or $\mathrm{CD} 27^{+}$phenotype profiles with no or low 
A

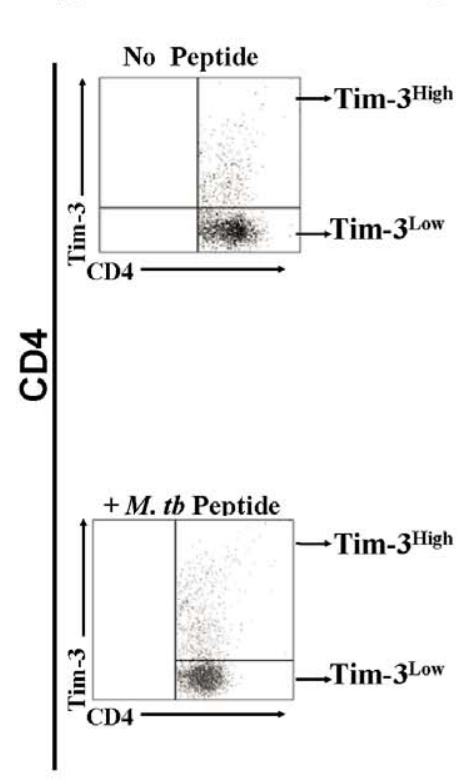

B
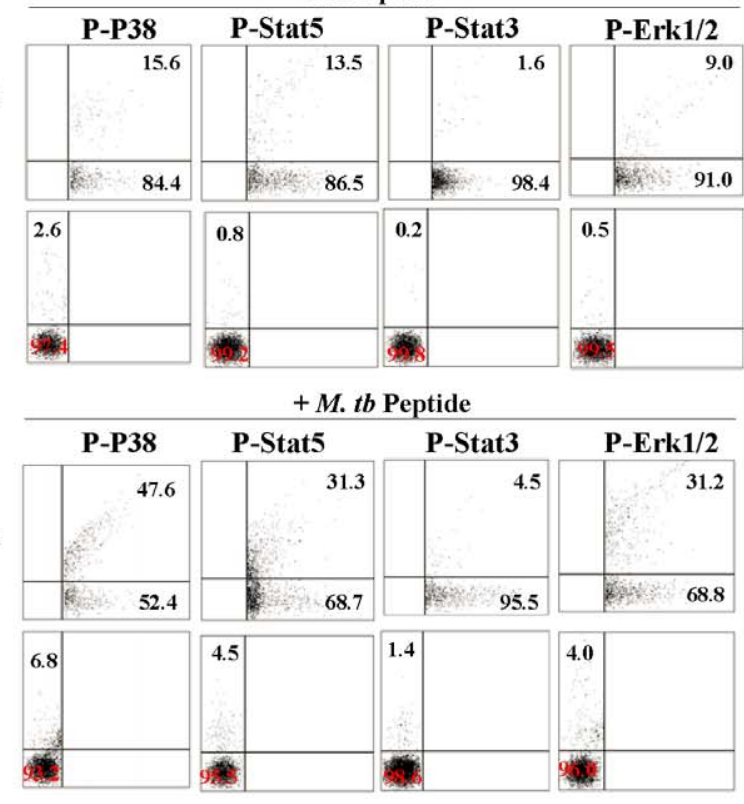

No Peptide
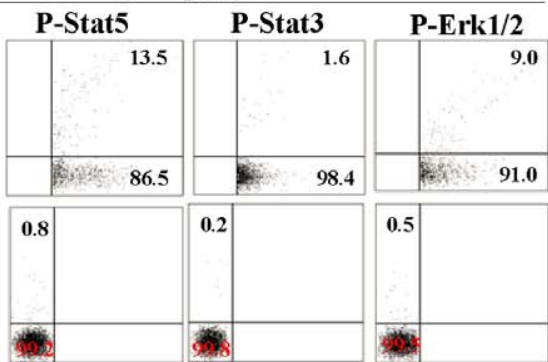

P-Stat3

P-Erk1/2
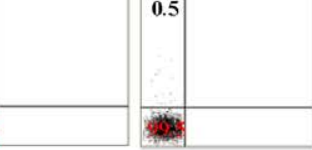

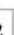

C
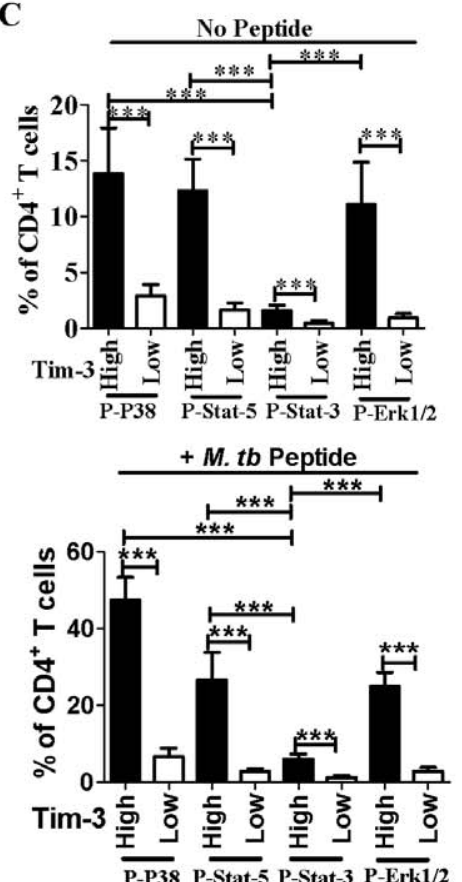

F

$\mathbf{E}$

No Peptide
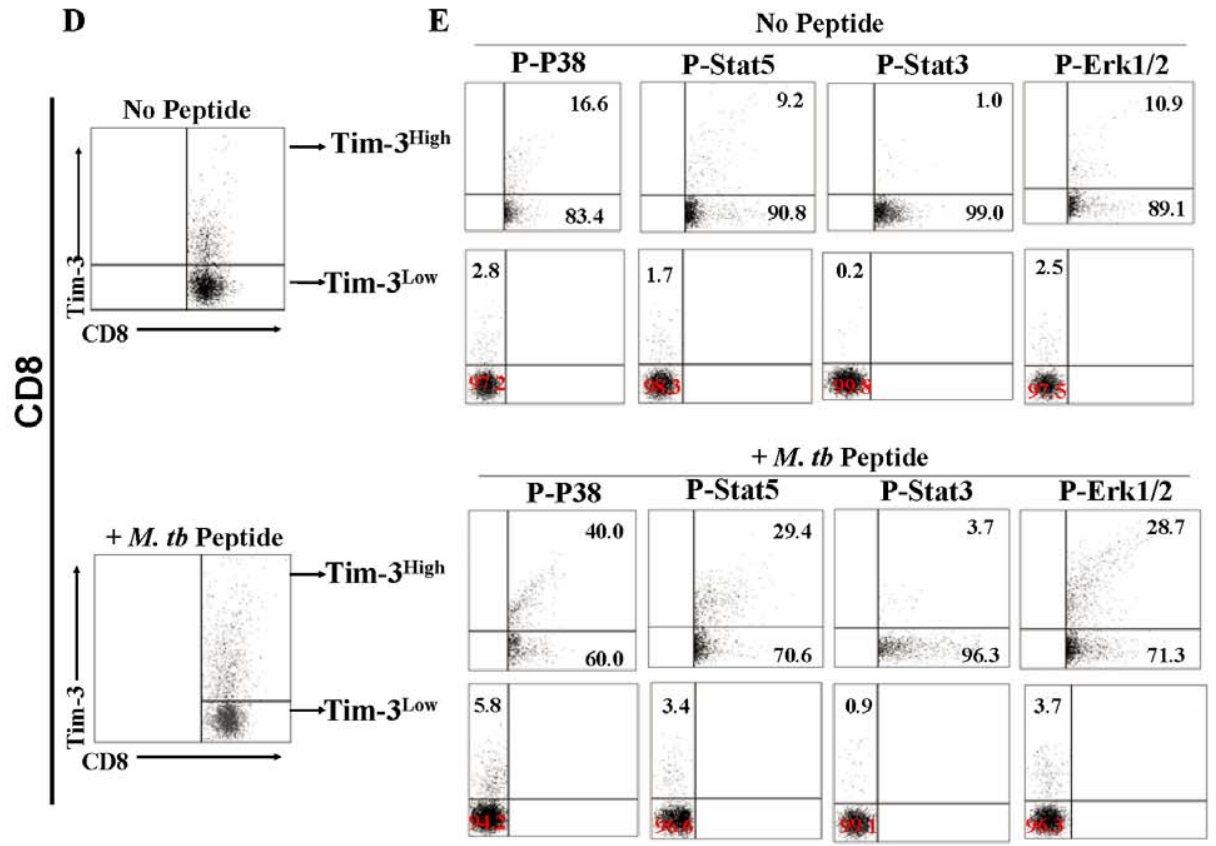
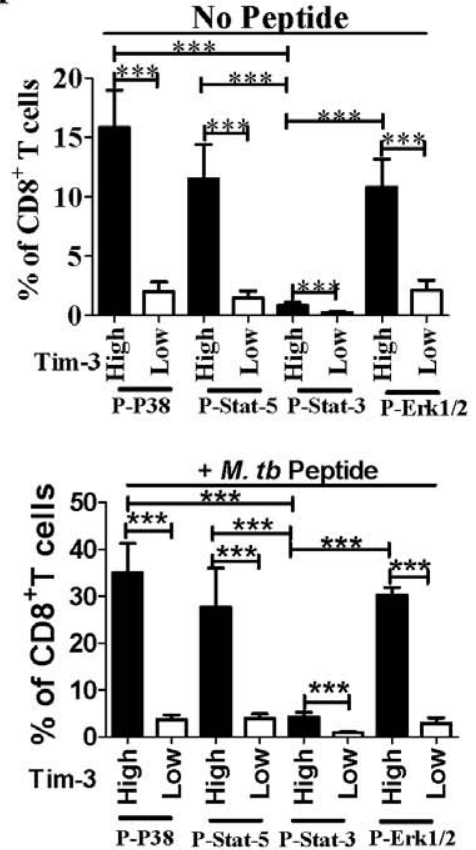

Figure 7. Tim-3-expressing $\mathrm{CD4}^{+}$and $\mathrm{CD8}^{+} \mathrm{T}$ cells from active TB patients exhibited stronger p38, stat3, stat5, and Erk1/2 signaling in cultures with or without Mtb peptide stimulation. Phosphorylation status of $p 38$, stat 5 , stat 3 , and Erk $1 / 2$ were analyzed by polychromatic flow cytometry in Tim- $3^{\text {High }}$ versus Tim- $3^{\text {Low }}$ T-cell subsets. PBMC from untreated active TB patients $(n=9)$ were stained directly without peptide stimulation or stained after 30 min ex vivo stimulation with pooled Ag85-b/ESAT-6 peptides, and assessed for expression of phosphorylated(P)-p38, P-stat5, P-stat3, or P-Erk1/2 cells in Tim- $3^{\text {High }}$ versus Tim- $3^{\text {Low }}$ T-cell subsets using flow cytometry analysis as described above. (A) and (D) shows a representative flow cytometric gating strategy for Tim- $3^{\mathrm{High}}$ and Tim- $3^{\mathrm{Low}} \mathrm{CD} 4^{+}$and $\mathrm{CD} 8+\mathrm{T}$ cells, respectively, to evaluate phosphorylated signaling molecules in cells cultured with or without ex vivo Mtb peptide stimulation. (B) shows representative flow cytometric dot plots demonstrating that expression levels of P-p38, P-stat5, P-stat3, and P-Erk1/2 were much higher in Tim- $3^{\text {High }} \mathrm{CD} 4^{+} \mathrm{T}$ cells than Tim- $3^{\text {Low }} \mathrm{CD} 4^{+} \mathrm{T}$ cells in the absence $($ upper panels) and presence (lower panels) of Mtb peptide stimulation. Values in dot plots indicate the percentages of expression levels of each of phosphorylated signaling molecule. Similar results were seen when Tim $-3^{+} \mathrm{T}$ cells were enriched by immunonmagnetic beads, and then cultured with or without Mtb peptide prior to flow analyses (data not shown). (E) is similar to (B) except for comparisons between Tim-3 ${ }^{\text {High }} \mathrm{CD} 8+\mathrm{T}$ cells Tim$3^{\text {Low }} \mathrm{CD}^{+} \mathrm{T}$ cells. (C) and (F) are bar graph data showing higher expression levels of P-p38, P-stat5, P-stat3, or P-Erk1/2 cells in Tim- $3^{\text {High }} \mathrm{CD} 4^{+}$or Tim$3^{\text {High }} \mathrm{CD}^{+} \mathrm{T}$ cells than Tim- $3^{\text {Low }} \mathrm{CD}^{+}$or Tim- $3^{\mathrm{LOW}} \mathrm{CD} 8^{+} \mathrm{T}$ cell subpopulations in the absence (upper panels) and presence (lower panels) of Mtb peptide stimulation (Lower panel). (C) and (F) show that percentages of expression of P-p38, P-stat5 and P-Erk1/2 are much higher than P-stat3 in Tim$3^{\text {High }} \mathrm{CD}^{+}$or Tim $-3^{\text {High }} \mathrm{CD} 8^{+}$T cells. Data are from at least two independent experiments. ${ }^{* * *} p<0.001$. Error bars represent SD. doi:10.1371/journal.ppat.1002984.g007 
expression of effector surrogate marker CD127 [16,19,20]. The discrepancy of Tim-3-expressing phenotypes between Mtb-infected and $\mathrm{HCV}$-infected or HIV-1-infected patients might result from the natures of pathogens/infections and distinct immune responses to virus versus mycobacteria. A dominant central memory and a lack of preferential effector phenotypes for Tim3-expressing T cells in HCV/HIV-1-infected patients may help to explain why the virus-driven Tim-3-expressing $\mathrm{CD}^{+} \mathrm{T}$ cells do not adequately produce effector cytokines in response to viral peptide stimulation in vitro $[16,19,20]$. In contrast, the predominant effector memory phenotypes of Tim-3-expressing $\mathrm{CD} 4^{+}$and $\mathrm{CD}^{+} \mathrm{T}$ cells in active $\mathrm{TB}$ patients are indeed consistent with enhanced effector functions for these Tim- $3^{\mathrm{High}} \mathrm{CD} 4^{+}$and Tim$3^{\text {High }} \mathrm{CD}^{+} \mathrm{T}$-cell subsets.

The ability of $\mathrm{Tim}-3^{+} \mathrm{T}$ cells to spontaneously produce cytokines in active TB appears to consist with our recent observation that active Mtb infection, but not SIV/SHIV infection or control setting, allows for intracellular cytokine staining (ICS) detection of cytokine production by T cells without the need for $e x$ vivo stimulation with Mtb antigens $[32,33,34]$. Such an ability to de novo produce cytokines by $\mathrm{T}$ cells from Mtb-infected humans or macaques might be due to the fact that a number of $\mathrm{T}$ cells have differentiated into highly activated Tim $-3^{+}$effector cells capable of producing cytokines in response to active TB-driven immune activation and inflammation. This notion is also supported by the finding that latent Mtb infection did not induce large numbers of $\mathrm{T}$ cells that spontaneously produce cytokines in cultures, as only $\leq 2.2 \%$ and $\leq 3.5 \%$ cells in Tim $-3^{+}$T cells of LTBI subjects were able to produce cytokines after culture with medium and Mtb peptide, respectively (Figure 2, Figure 3). The high levels of Tim$3^{+} /$cytokine $^{+} \mathrm{T}$ cells in active $\mathrm{TB}$ might be attributed partially to the $\mathrm{BCG}$ vaccination background in active $\mathrm{TB}$ patients, as all these patients had BCG vaccination history.

The present study uncovers a surprising finding that Tim- $3^{\text {High }}$ $\mathrm{CD}^{+}$and ${ }^{\mathrm{Tim}}-3^{\mathrm{High}} \mathrm{CD}^{+}$T-cell subsets exhibited greater effector functions for producing Th1/Th22 cytokines and CTL effector molecules. These enhanced effector functions of Tim-3expressing $\mathrm{T}$ cells in $\mathrm{TB}$ are not totally unexpected as antimicrobial effector functions of $\mathrm{T}$ cells are usually linked to effector or effector memory phenotypes of these T cells [30,31], and such enhanced effector functions appear to reflect the immunological features of effector memory phenotypes for Tim- $3^{\text {High }} \mathrm{CD} 4^{+}$and $\mathrm{CD}^{+} \mathrm{T}$-cell subsets. Furthermore, enhanced effector functions of Tim-3-expressing $\mathrm{T}$ cells are also supported by the results from our mechanistic studies of cellular activation/signaling molecules as Tim- $3^{\mathrm{High}} \mathrm{CD}^{+}$and $\mathrm{CD}^{+}{ }^{+} \mathrm{T}$-cell subsets in active $\mathrm{TB}$ patients expressed higher levels of phosphorylated signaling molecules p38, stat3, stat5, and Erk1/2. Despite the fact that the downstream molecular activation events for Tim-3 regulation of $\mathrm{T}$ cells are largely unknown [41], the up-regulated expression of phosphorylated signaling molecules in Tim- $3^{\text {High }} \mathrm{T}$-cell subsets may help to explain stronger effector functions in Tim-3-expressing $\mathrm{CD} 4^{+}$and $\mathrm{CD}^{+} \mathrm{T}$ cells in active TB. The notion that stronger effector functions are driven by greater signaling in Tim-3-expressing $\mathrm{T}$ cells is also consistent with a recent finding that Tim-3 may augment $\mathrm{T}$-cell signaling after a short-term stimulation [41]. This connection is also supported by the data from HIV-1-infected humans since impaired phosphorylation of above intracellular signaling molecules correlates with reduced effector functions of Tim-3-expressing $\mathrm{CD}^{+} \mathrm{T}$ cells in HIV infection [19]. A recent study reported that Tim-3-expressing CD8 ${ }^{+} \mathrm{T}$ cells in TB patients produced lower levels of IFN- $\gamma$ than healthy controls [18]. However, subtle IFN- $\gamma$ responses were detected in both TB and control groups due to the use of ESAT-6 protein, instead of peptide pool, for in vitro stimulation [18]. It is important to note that $\mathrm{CD}^{+} \mathrm{T}$ cells respond poorly to whole protein and that recombinant Mtb ESAT-6 protein actually inhibits T-cell production of IFN- $\gamma$ [42]. Future studies using MHC I/peptide and MHC II/peptide tetramers will provide a better system in which to elucidate phenotypes and effector functions of Ag-specific Tim $-3^{+} \mathrm{CD} 4^{+}$and Tim $-3^{+} \mathrm{CD} 8^{+} \mathrm{T}$ cells.

Our results suggest that Tim-3-expressing $\mathrm{CD} 4^{+}$and $\mathrm{CD}^{+}{ }^{+} \mathrm{T}$ cell subsets possess much broader repertoire of effector functions than what was previously described. Earlier studies implicated that Tim-3 might be an exclusive cell surface marker for Th1 cells [9], and it remains unknown whether Tim-3-expressing $\mathrm{CD}^{+} \mathrm{T}$ cells in human TB could differentiate into Th22 and Th17 subsets capable of mounting immune responses to Mtb infection [32,34]. The current study demonstrates that Tim-3-expressing CD4 ${ }^{+} \mathrm{T}$ cells not only can produce Thl cytokines(IFN- $\gamma$, IL-2), but also produce appreciable amounts of IL-22, IL-4 (data not shown), and IL-17A (data not shown), suggesting that Tim- $3^{\text {High }} \mathrm{CD} 4^{+}$T-cell subset in active $\mathrm{TB}$ are capable to differentiate into Th1, Th2, Th22/Th1 7 cells. Interestingly, Tim- $3^{\text {High }}$ CD ${ }^{+}$T-cell subset in active TB also exhibits broad effector functions producing the above cytokines and cytotoxic molecules. Furthermore, human Tim-3-expressing $\mathrm{T}$ cells can function as anti-Mtb effector cells limiting intracellular Mtb growth. Our results are consistent with a recent observation that mouse Tim-3-Gal-9 interaction can lead to inhibition of Mtb replication in macrophages [37]. The broad effector repertoires of Tim-3-expressing $\mathrm{CD}^{+}$and $\mathrm{CD}^{+} \mathrm{T}$ cells might be advantageous from the standpoints of host immune responses to Mtb infection.

The findings from our mechanistic experiments suggest that Tim-3 signaling pathways help to enhance effector functions of producing Th1, Th22 cytokines and CTL molecules. Particularly, we show that Tim-3 silencing by siRNA Tim-3 leads to reduced $d e$ novo production of IFN- $\gamma$ and TNF- $\alpha$ by Tim-3-expressing $\mathrm{T}$ cells, and that soluble Tim-3 treatment interfering with membrane Tim3-ligand interaction can also decrease Tim-3-driven activation and effector functions of cytokine production. On the other hand, we demonstrate that stimulation of Tim-3 signaling pathway by $\mathrm{Ab}$ cross-linking of membrane Tim-3 can enhance effector function of IFN- $\gamma$ production by $\mathrm{CD}^{+}$and $\mathrm{CD}^{+} \mathrm{T}$ cells. These findings appear to be inconsistent with what were reported in HCV- and HIV-1-infected patients [16,19]. It has been implicated that expression of Tim-3 on $\mathrm{CD}^{+} \mathrm{T}$ cells may be linked to progressive loss of secretion of Th1 cytokines such as IL-2, TNF- $\alpha$ and IFN- $\gamma$ in HCV and HIV-1 infections [15,16,19,21,22]. Nevertheless, these Tim-3-associated negative effects can be explained at least partially by the phenotypic features and impaired activation signaling of Tim-3-expresssing $\mathrm{CD}^{+} \mathrm{T}$ cells in those virus-infected persons. Tim-3-expressing $\mathrm{CD}^{+} \mathrm{T}$ cells in HCV- and HIV-1infected patients predominantly express central memory phenotypes, rather than effector and effector memory phenotypes $[16,19]$; HIV-1 infection leads to impaired Stat5, Erk1/2, and p38 signaling in Tim-3-expressing CD8 ${ }^{+} \mathrm{T}$ cells [19]. On the contrary, active $\mathrm{TB}$ drives predominant effector memory phenotypes and stronger cellular activation signaling. It is likely that HCV or HIV1 infection preferentially induces Tim-3-associated central memory or non-effector phenotypes with depression or low levels of cellular signaling, whereas Mtb infection can drive effector memory Tim-3-expressing T cells with enhanced Tim-3 signaling pathways for stronger effector functions. It is noteworthy that studies done to date have only identified Gal-9 as Tim-3 ligand [17], and precise Tim-3-induced signaling pathways remain incompletely understood [17]. From these points of views, we cannot exclude the possibility that viral and Mtb infections would 
engage in independent co-activation signals in $\mathrm{T}$ cells and induce potential different Tim-3 ligands in infected target cells.

It is currently not known whether increased numbers of Tim$3^{\mathrm{High}} \mathrm{CD}^{+}$and $\mathrm{CD}^{+} \mathrm{T}$ effector cells in active TB patients are detrimental or beneficial in active Mtb infection. Given that such increases are seen in the setting of active TB, Tim-3-expressing $\mathrm{T}$ cells might act as over-reactive effector cells and contribute to TB inflammation and pathologic lesions. This notion is supported by the finding that healthy subjects with LTBI exhibited much lower levels of Tim $-3^{+} \mathrm{CD} 4^{+}$and Tim $-3^{+} \mathrm{CD} 8^{+} \mathrm{T}$ effector cells producing cytokines. Over production of IFN- $\gamma$ and TNF- $\alpha$ by Tim-3expressing $\mathrm{T}$ cells may indeed elevate degree of inflammation or damages in active TB, although mouse IFN- $\gamma$ and TNF- $\alpha$ are important for controlling Mtb infection [30,43,44,45,46,47,48,49]. On the other hand, increases in Tim-3-expressing $\mathrm{CD}^{+}$and $\mathrm{CD}^{+} \mathrm{T}$ cells might result from host responses to high Mtb burden due to postprimary $\mathrm{TB}$ or reactivation $\mathrm{TB}$. These responses, although unable to control TB, might develop as disorganized host defense or otherwise reflect protective potential if immune responses to $\mathrm{TB}$ can be well coordinated or if pathogenic events leading to high levels of Mtb burden can be intervened. This scenario appears to be supported by the data from the current study since Tim-3-expressing $\mathrm{T}$ cells can produce anti-Mtb cytokines IFN- $\gamma / \mathrm{TNF}-\alpha /$ IL-22, and function as effector cells limiting intracellular Mtb growth in macrophages.

Thus, the current study demonstrate that Tim-3-expressing $\mathrm{CD}^{+}$and $\mathrm{CD}^{+} \mathrm{T}$ cells in active $\mathrm{TB}$ patients exhibit polarized effector memory phenotypes and stronger, but not impaired, antimycobacterium effector functions. Our findings therefore may suggest a new paradigm for $\mathrm{T}$-cell immune responses regulated by Tim-3 expression in human $\mathrm{TB}$, and have implications for potential immune intervention in TB.

\section{Materials and Methods}

\section{Subjects}

The active Mtb infection in patients was confirmed based on clinical symptoms, chest radiography, and sputum stain for acidfast bacilli (AFB), culture and PCR for Mtb, which were done in Shenzhen Third People's Hospital. Subsequently, patients confirmed with $\mathrm{Mtb}$ infection received individualized regimens with rifampicine and isoniazide plus either streptomycin or ethambutol. After initiation of TB treatment, patients were evaluated again clinically and bacteriologically to determine the effectiveness of the therapy and the transition of disease. Healthy controls (HCs) are a cohort of individuals negative for tuberculin skin test (TST) with no bacteriological and clinical evidence of TB disease. Subjects with LTBI are a cohort of individuals strongly positive for TST with no bacteriological and clinical evidence of active TB disease. All samples of Mtb-infected individuals or healthy controls were collected with informed written consent according to protocols approved by the Internal Review and the Ethics Boards of Shenzhen Third People's Hospital and Zhongshan School of Medicine of Sun Yat-sen University.

\section{Monoclonal antibodies (mAbs), protein and peptides}

Abs against the following molecules were used: CD3-FITC, CD3-PE, CD3-APC, or CD3-PE/Cy7 (Clone OKT3, ebioscience); CD4-APG, CD4-PE, CD4-PE/Cy7, or CD4-Biotin (Glone RPA-T4, BD); CD8-APG, GD8-PE, CD8-PE/Cy7, or CD8-Biotin (Clone RPA-T8, BD); Tim-3-PE, Tim-3-Alexa fluor488 (Clone 344823, R\&D); CCR7(CD197)-FITC (Clone 3D12, ebioscience), CD27-APC (Clone O323, ebioscience), CD45RA-PE/Cy7 (Clone HI100, ebioscience), CD127-FITC
(Clone eBioRDR5, ebioscience), CD62L-PE (Clone DREG56, ebioscience); TNF- $\alpha$-APG, TNF- $\alpha$-FITC(Clone Mab11, ebioscience); IFN- $\gamma$-FITC, IFN- $\gamma$-APG (Clone 4s.b3, ebioscience); Granzyme B-FTIC (Clone GB11, BD), perforin-FITC (Clone deltaG9, ebioscience); IL-2-FITC (Clone MQ1-17, BD), IL-4APG (Clone 8D4-8, ebioscience), IL-17a(Clone eBio64DEG17, ebioscience), IL-22-PE (Clone 22URTI, ebioscience), PE-antiGalectin-9(Clone 9M1-3, biolegend), anti-IL-1 $\beta$ (Clone AS10, BD). Streptavidin-Phycoerythrin-Texas Red (BD) was used to conjugate CD4-biotin or CD8-biotin antibody. Recombinant human Tim-3 $\mathrm{F}_{\mathrm{C}}$ Chimera (i.e.Tim-3-Ig) and the purified Ab for Tim-3 (Clone 344823) were both from R\&D. Overlapping Mtb Ag85-b/ESAT6 pooled peptides(15 a.a. overlapped by 12 spanning entire Ag85 or ESAT6 protein were synthesized and used as we previously described [34]. The purpose choosing combined peptides for ICS was to maximize detection of Mtb-specific $\mathrm{T}$ effector cells and to optimally work with a limited amount of blood volume collected from individual subjects.

Isolation of peripheral blood mononuclear cells (PBMC), intracellular cytokine staining (ICS) and flow cytometric analysis

PBMC were isolated from whole blood by Ficoll (GE health) density gradient centrifugation, as we described previously [32]. Intracellular cytokine staining (ICS) was done as we previously described [32]. We used two approaches for ICS: (i) PBMC from untreated active TB patients were stimulated ex vivo with Mtb peptides pool, and then stained for Tim-3 and anti-Mtb effector cytokines including IFN- $\gamma$, TNF- $\alpha$, IL-2, and IL-22 and analyzed by polychromatic flow cytometry.. (ii) PBMC from the same TB patients were directly stained for the above cytokines without peptide stimulation as we recently described [32,34]. The specificity and utility of the direct intracellular cytokine staining approach has been validated during Mtb infection of macaques and humans as well as in the control settings [32,33,34]. Briefly, PBMC were cultured with or without re-stimulation with Mtb Ag85-b/ESAT-6 peptide pools for 6 hours in presence of brefeldin $\mathrm{A}(5 \mu \mathrm{g} / \mathrm{ml}$; BD) in the final 3 hours of culture. Cells were then fixed, permeabilized and washed with the Perm/Wash buffer (BD). For PBMC without in vitro antigenic re-stimulation, cells were fixed, permeabilized and washed with the BD Perm/Wash buffer. After permeabilization, cells were stained using fluochrome-conjugated mAbs or isotype control Abs. Data were acquired on Beckman Coulter Cytomics FC500 (Beckman) and analyzed with CXP (Beckman) software.

\section{Ligand competition assay using soluble form of Tim-3(s- Tim-3)}

PBMC derived from TB patients were incubated with $2 \mu \mathrm{g} / \mathrm{ml}$ soluble form of Tim-3 molecules (human Tim-3 Fc Chimera, purchased from R\&D) in presence or absence of Mtb Ag85-b/ ESAT- 6 pooled peptides for 6 days. Production of IFN- $\gamma$ and TNF- $\alpha$ by Tim-3-expressing T cells were then analyzed using ICS protocol and flow cytomery.

\section{Tim-3 stimulation assay using cross-linking Tim-3-specific} monoclonal Ab (mAb)

PBMC from subjects with active TB patients were incubated with $10 \mu \mathrm{g} / \mathrm{ml}$ of purified mouse anti-human mAb against Tim-3 (purchased from R\&D) or isotype control $\operatorname{IgG}(10 \mu \mathrm{g} / \mathrm{ml})$ in presence or absence of Mtb Ag85-b/ESAT-6 pooled peptides for 6 days. The effects of Tim-3 mAb stimulation on the production of 
IFN- $\gamma$ and TNF- $\alpha$ by Tim-3-expressing T cells were then analyzed using ICS protocol and flow cytometry.

\section{Staining of intracellular signaling molecules}

PBMC from active TB patients were stimulated with Mtb Ag85b/ESAT-6 pooled peptides for 30 mins. After fixation and subsequent washing, cells were permeabilized with Perm/Wash buffer (BD). Cells were washed and stained with isotype control Ab or fluochrome-conjugated phosphospecific Abs: P-stat3 (pY705)PE (Clone 4/P-STAT3, BD), P-erk1/2(pT202/pY204)-Alexa Fluor488 (Clone 20A, BD), P-p38 (pT180/pY182)-Alexa fluor 647 (Clone 36, BD), or P-stat5 (pY694)-FITC (Clone 47, BD).

\section{Knockdown of Tim-3 via siRNA}

PBMC derived from TB patients were transiently transfected with $20 \mathrm{nM}$ siRNA targeting Tim-3 (si-Tim-3) or $20 \mathrm{nM}$ nontargeting siRNA (si-control) using Lipofectamine 2000 (Invitrogen). siRNA targeting Tim-3 (si-Tim-3) and nontargeting siRNA (si-control) are commercially available from Ribobio (Guangzhou, China). Knockdown efficiency was analyzed by real-time PCR or flow cytometry 48 hours after transfection. At 2 days after transfection, PBMC were cultured in presence or absence of Mtb Ag85-b/ESAT-6 peptide pools for 6 days, and cytokine production was analyzed by ICS and flow cytometry.

\section{Isolation of monocytes and $\mathrm{Tim}-3^{+} \mathrm{CD}^{+} \mathrm{T}$ cells}

Cell isolation was done as we described previously [34]. Briefly, PBMC were isolated from the blood of active TB patients, and monocytes were obtained by adherence purification on plastic plates. The plates were washed after 2 hours of adherence, and monocytes were detached by cold $2 \%$ FBS/PBS. The nonadherent cell fraction containing $\mathrm{T}$ cells was stained with antiTim-3-PE (ebioscience), followed by anti-PE magnetic beads (Miltenyi Biotec). The stained live cells were then loaded to the purification column following instructions from the manufacturer. The passing fraction was collected as Tim- $3^{-}$(negative) cells that did not bear Tim-3; Tim- $3^{+} \mathrm{T}$ cells held by anti-PE magnetic beads were then released by releasing buffer (Miltenyi Biotec). The isolated Tim $-3^{+} \mathrm{T}$ cells were stained again with anti-CD3 FITC (BD), followed by anti-FITC magnetic microbeads for secondary purification. The purity of isolated Tim $-3^{+} \mathrm{CD} 3^{+} \mathrm{T}$ cells and Tim$3^{-} \mathrm{CD}^{+} \mathrm{T}$ cells is over $95 \%$ ([34], data not shown).

\section{In vitro Mtb infection of monocytes-derived macrophages and intracellular Mtb growth assay}

This was done similarly like what we recently described [34]. Briefly, autologous monocytes $\left(5 \times 10^{4} /\right.$ well $)$ were cultured in round-bottom 96-well plates with 10\% FBS-RPMI 1640 medium in presence of human rIL-4 (BD) and GM-CSF (Sigma-Aldrich) for 8 days. Supernatants were then removed, and Mtb (H37Ra) inoculum was added at a $\mathrm{MOI}=1$. After overnight infection at $37^{\circ} \mathrm{C}$, supernatants were aspirated and each well was washed extensively to remove extracellular Mtb. Enriched Tim- $3^{+} \mathrm{CD} 3^{+} \mathrm{T}$ cells $\left(5 \times 10^{5} /\right.$ well $)$ or Tim $-3^{-} \mathrm{CD}^{+} \mathrm{T}$ cells $\left(5 \times 10^{5} /\right.$ well $)$ were incubated with Mtb-infected macrophages $(\mathrm{M} \Phi \mathrm{s})$ in presence or absence of anti-IL-1 $\beta \mathrm{Ab}(10 \mu \mathrm{g} /$ $\mathrm{ml})$ or $\operatorname{IgG}(10 \mu \mathrm{g} / \mathrm{ml})$. After culturing in $5 \% \mathrm{CO}_{2}$ at $37^{\circ} \mathrm{C}$ for 4 days, wells were aspirated, and lysis buffer $(0.067 \%$ SDS in Middlebrook 7H9) was added to each well. Plates were incubated at $37^{\circ} \mathrm{C}$, followed by neutralization of SDS with PBS with $20 \%$ BSA. Lysates from each well were pooled, and two 10-fold serial dilutions of lysate in $7 \mathrm{H} 9$ medium were made. Aliquots of each dilution of lysate and supernatant were plated onto Middlebrook 7H10 agar and incubated until colonies were large enough to be counted.

\section{Statistical analysis}

Statistical significance was determined with Student $t$-test (difference between two groups or conditions), and a $p$ value $<0.05$ in all cases was considered statistically significant $(95 \%$ confidence interval), as we described previously [32]. Analysis was performed using Prism 5.0 software (GraphPad Software, Inc.).

\section{Supporting Information}

Figure S1 TB infection led to up-regulation of Galectin9 (Gal-9) expression and increases in numbers of Gal-9expressing $\mathrm{CD4}^{+}$and $\mathrm{CD8}^{+} \mathbf{T}$ cells. PBMCs were stained using ICS protocol. (A) is representative flow cytometric dot plots showing Gal-9 expression in a healthy control (HC), a representative individual with LTBI, or a typical individual with untreated active TB disease. No Gal-9 expression was observed when we used isotype matched IgG to stain PBMCs (Data not shown). Values in the upper right quadrant indicate the percentages of Gal-9-expressing $\mathrm{CD}^{+}{ }^{+}$and $\mathrm{CD} 8^{+} \mathrm{T}$ cells. Data were gated on $\mathrm{CD}^{+} \mathrm{CD}^{+}$and $\mathrm{CD} 3^{+} \mathrm{CD}^{+}$, respectively. $(\mathrm{B})$ and $(\mathrm{C})$ are pooled flow cytometric data showing that the percentages (\%) of Gal-9 expression on $\mathrm{CD}^{+}$and $\mathrm{CD}^{+} \mathrm{T}$ cells from 9 subjects with active TB disease are much higher than either 9 subjects with LTBI or 9 healthy control (HCs). Horizontal bars depict the mean percentage of Mtb-specific Gal-9 expression on $\mathrm{CD}^{+}$and $\mathrm{CD}^{+}{ }^{+} \mathrm{T}$ cells. *** $p<0.001, * * p<0.01, * p<0.05$.

(PDF)

Figure S2 Tim-3-expressing $\mathrm{CD4}^{+}$and $\mathrm{CD8}^{+} \mathrm{T}$ cells in active TB patients preferentially exhibited effector memory, but not central memory, phenotypes. PBMCs isolated from untreated active TB patients $(n=9)$ were cultured with or without ex vivo stimulation of pooled Ag85-b/ESAT-6 peptides, stained with fluorochrome-conjugated mAbs, analyzed by polychromatic flow cytometry. (A) is representative flow cytometric dot plots showing the CCR7 and CD45RA expression in Tim-3-expressing $\mathrm{CD}^{+}{ }^{+}$and $\mathrm{CD}^{+} \mathrm{T}$ cells from a Mtb-infected individual with untreated active $\mathrm{TB}$ disease (gated on $\mathrm{CD}^{+}{ }^{+} \mathrm{CD} 4^{+} \mathrm{Tim}^{-} 3^{+}$and $\mathrm{CD} 3^{+} \mathrm{CD} 8^{+} \mathrm{Tim}-3^{+}$, respectively). Values in each quadrant indicate the percentages of $\mathrm{CD} 45 \mathrm{RA}^{+} \mathrm{CCR} 7^{+}$, CD45RA ${ }^{-} \mathrm{CGR}^{+}, \mathrm{CD}^{+} 5 \mathrm{RA}^{-} \mathrm{CGR}^{-}, \mathrm{CD}^{-} 5 \mathrm{RA}^{+} \mathrm{CGR}^{-}$cells. (B) and $(\mathrm{C})$ are pooled data showing the preferential expression of CD45RA ${ }^{-} \mathrm{CCR}^{-}{ }^{-}$effector memory phenotype in Tim-3-expressing $\mathrm{CD}^{+}$and $\mathrm{CD}^{+} \mathrm{T}$ cells of Mtb-infected individuals $(\mathrm{n}=9)$. Data shown are representative of at least three independent experiments. $* p<0.05$, ** $p<0.01$, *** $p<0.001$.

(PDF)

Figure S3 M.tb-specific $\mathrm{CD4}^{+}$and $\mathrm{CDB}^{+} \mathrm{T}$ cells expressing Tim-3 lack expression of CD27 and CD62L, but have higher expression levels of GD127. PBMCs of Mtb-infected individuals with untreated active TB disease $(n=9)$ were stained directly or re-stimulated using pooled Ag85-b/ESAT-6 peptides. (A), (D), and (G) are representative flow cytometric dot plots (gated on $\mathrm{CD} 3+\mathrm{CD} 4+$ ) showing that less CD27 (A) and CD62L molecule (D), but more CD127 (G) expressed on Tim-3-expressing Mtbspecific $\mathrm{CD}^{+}$and $\mathrm{CD}^{+}{ }^{+}$T cells. Numbers in upper right quadrant of each flow cytometric dot plot indicate the percentages of CD $27^{+}$Tim $3^{+}$, CD $62 \mathrm{~L}^{+}$Tim $-3^{+}$, or $\mathrm{CD} 127^{+}$Tim $-3^{+}$cells. $(\mathrm{B}),(\mathrm{C})$, $(\mathrm{E}),(\mathrm{F}),(\mathrm{H})$, and $(\mathrm{I})$ are pooled data showing that Tim-3-expressing Mtb-specific $\mathrm{CD}^{+}$and $\mathrm{CD}^{+} \mathrm{T}$ cells contained much smaller percentages of $\mathrm{CD} 27^{+}$or $\mathrm{CD} 62 \mathrm{~L}^{+} \mathrm{T}$ cells, but greater percentages of $\mathrm{CD} 127^{+} \mathrm{T}$ cells. Data shown are representative of at least three independent experiments. Error bars represent SD. *** $p<0.001$. (PDF) 
Figure $\mathrm{S4}$ Tim-3-expressing $\mathrm{CD4}^{+}$and $\mathrm{CD8}^{+} \mathrm{T}$ cells in subjects with active TB disease or LTBI preferentially exhibited CD27 ${ }^{-}$CD45RA $^{-}$phenotypes. PBMCs isolated from subjects with untreated active TB disease $(n=9)$ or with LTBI ( $\mathrm{n}=9$ ) were cultured with or without ex vivo stimulation of pooled Ag85-b/ESAT-6 peptides, stained with fluorochromeconjugated mAbs, analyzed by polychromatic flow cytometry. (A) is representative flow cytometric dot plots showing the expression of CD27 and CD45RA in Tim-3-expressing CD4 ${ }^{+}$and $\mathrm{CD}^{+}{ }^{+} \mathrm{T}$ cells from a Mtb-infected individual with untreated active TB disease (gated on $\mathrm{CD}^{+}{ }^{+} \mathrm{CD} 4^{+} \mathrm{Tim} 3^{+}$and $\mathrm{CD} 3^{+} \mathrm{CD} 8^{+} \mathrm{Tim}-3^{+}$, respectively). (D) Similar representative flow cytometric dot plot show the expression of CD27 and CD45RA in a subject with LTBI. Values in each quadrant indicate the percentages of

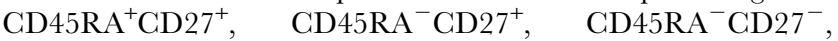
CD45RA ${ }^{+} \mathrm{CD} 27^{-}$cells. (B) and (C) Pooled data show the preferential expression of $\mathrm{CD} 27^{-} \mathrm{CD} 45 \mathrm{RA}^{-}$phenotype in Tim3-expressing $\mathrm{CD}^{+}$and $\mathrm{CD}^{+} \mathrm{T}$ cells derived from the individuals with active TB $(\mathrm{n}=9)$. Data shown are representative of at least three independent experiments. (E) and (F) show the similar pooled data in LTBI. Error bars represent SD. *** $p<0.001$.

(PDF)

Figure S5 Tim-3 ${ }^{\text {High }}$ CD4 $^{+}$T cells show much stronger Mtb-specific TNF- $\alpha$, IL-2, and IL-22 responses than their Tim-3 ${ }^{\text {Low }}$ counterparts. PBMCs derived from 9 TB patients with untreated active TB disease or 9 individuals with LTBI were stimulated, stained, and analyzed as like $\mathrm{CD} 4^{+} \mathrm{T}$ cells shown in Figure 2. Tim- $3^{\text {High }}$ and Tim- $3^{\text {Low }}$ populations were gated to analyze the relationship between Tim-3 expression and IL-2, IL-22 and TNF- $\alpha$ responses of CD $4^{+} \mathrm{T}$ cells. Numbers in each of dot plots represent the percentages of IL-2-, IL-22-, or TNF- $\alpha$-producing CD $4^{+} \mathrm{T}$ cells. (A), (C), and (E) are representative flow cytometric dot plots showing de novo and Mtb-specific cytokine responses of TNF- $\alpha$, IL-2 , and IL-22 in Tim- $3{ }^{\mathrm{High}} \mathrm{CD} 4^{+} \mathrm{T}$ cell and Tim- $3^{\text {Low }} \mathrm{CD} 4^{+} \mathrm{T}$ cells from an individual with active TB disease. $(\mathrm{G}),(\mathrm{I})$, and $(\mathrm{K})$ shows that similar responses of TNF- $\alpha$, IL-2, and IL-22 were also observed in Tim- $3^{\mathrm{High}} \mathrm{CD} 4^{+} \mathrm{T}$ cell and $\mathrm{Tim}-3^{\mathrm{Low}} \mathrm{CD} 4^{+} \mathrm{T}$ cells from an individual with LTBI. (B) is pooled flow cytometric data from individuals with active $\mathrm{TB}$ disease $(\mathrm{n}=9)$ show that the percentages of TNF- $\alpha^{+} \mathrm{CD} 4^{+} \mathrm{T}$ cells are much higher in $\mathrm{Tim}-3^{\mathrm{High}} \mathrm{CD} 4^{+} \mathrm{T}$ cells than those in Tim$3^{\text {Low }} \mathrm{CD} 4^{+} \mathrm{T}$ cells. Similar pooled flow cytometric data in (D) and $(\mathrm{F})$, respectively, show that $\mathrm{Tim}-3^{\mathrm{High}} \mathrm{CD} 4^{+} \mathrm{T}$ cells contained much higher percentages of $\mathrm{IL}-2^{+} \mathrm{CD} 4^{+} \mathrm{T}$ cells or IL- $22^{+} \mathrm{CD} 4^{+} \mathrm{T}$ cells than their Tim- $3^{\text {Low }}$ counterparts. $(\mathrm{H}),(\mathrm{J})$, and $(\mathrm{L})$ are similar pooled data from 9 individuals with LTBI show that $\mathrm{Tim}-3^{\mathrm{High}} \mathrm{CD} 4^{+} \mathrm{T}$ cells contained much higher percentages of $\mathrm{TNF}-\alpha^{+} \mathrm{CD} 4^{+} \mathrm{T}$ cells, IL- $2^{+} \mathrm{CD} 4^{+} \mathrm{T}$ cells , and IL- $22^{+} \mathrm{CD} 4^{+} \mathrm{T}$ cells than their Tim- $3^{\text {Low }}$ counterparts. Data shown are representative of at least three independent experiments. Error bars represent SD. ${ }^{* * *} p<0.001, * p<0.05$. (PDF)

Figure S6 Tim-3 ${ }^{\mathrm{High}} \mathrm{CD8}^{+} \mathrm{T}$ cells show stronger de novo or Mtb-specific responses of TNF- $\alpha$ and IL-2 than Tim$3^{\text {Low }}$ CD8 $^{+}$T cells. PBMCs derived from 9 individuals with untreated active TB disease or 9 individuals with LTBI were stimulated, stained, and analyzed using the same protocol as shown in Figure 2. Tim- $3^{\text {High }}$ and Tim- $3^{\text {Low }}$ populations were gated to analyze the relationship between Tim-3 expression and TNF- $\alpha$ and IL- 2 responses of CD ${ }^{+}$T cells. Numbers in dot plots indicate the percentages of TNF- $\alpha$ - or IL-2-expressing $\mathrm{CD}^{+} \mathrm{T}$ cells. (A) and (C) are representative flow cytometric dot plots show de novo or Mtb-specific TNF- $\alpha$ and IL-2 responses in Tim$3^{\text {High }} \mathrm{CD}^{+} \mathrm{T}$ cell and Tim- $3^{\text {Low }} \mathrm{CD}^{+} \mathrm{T}$ cells from an individual with active TB disease. $(\mathrm{E})$ and $(\mathrm{G})$ are similar representative flow cytometric dot plots showing the similar de novo or Mtb-specific TNF- $\alpha$ and IL-2 responses in Tim- $3{ }^{\mathrm{High}} \mathrm{CD}^{+} \mathrm{T}$ cell and Tim$3^{\text {Low }} \mathrm{CD}^{+} \mathrm{T}$ cells from an individual with LTBI. (B) and (D) are pooled flow cytometric data from individuals with active TB disease showing that the percentages of either TNF- $\alpha^{+} \mathrm{CD}^{+} \mathrm{T}$ cells or IL- $2^{+} \mathrm{CD} 8^{+} \mathrm{T}$ cells are much higher in Tim- $3^{\mathrm{High}} \mathrm{CD} 8^{+} \mathrm{T}$ cells, as compared to Tim- $3^{\text {Low }} \mathrm{CD}^{+} \mathrm{T}$ cells $(\mathbf{n}=9)$. $(\mathbf{F})$ and $(\mathbf{H})$ are similar pooled data from individuals with LTBI show that the percentages of either TNF- $\alpha^{+} \mathrm{CD} 8^{+} \mathrm{T}$ cells or $\mathrm{IL}-2^{+} \mathrm{CD} 8^{+} \mathrm{T}$ cells are much higher in Tim- $3{ }^{\mathrm{High}} \mathrm{CD} 88^{+} \mathrm{T}$ cells, as compared to Tim$3^{\text {Low }} \mathrm{CD}^{+} \mathrm{T}$ cells $(\mathrm{n}=9)$. Data shown are representative of at least three independent experiments. Error bars represent SD. $* p<0.05, * * p<0.01, * * * p<0.001$.

(PDF)

Figure S7 Tim-3 expression is associated with stronger granzyme B response of Mtb-specific $\mathrm{CD4}^{+}$and $\mathrm{CD8}^{+} \mathrm{T}$ cells. PBMCs derived from individuals with untreated active TB disease $(n=9)$ or with LTBI $(n=9)$ were cultured in presence or absence of pooled Ag85-b/ESAT-6 peptides, and analyzed as like perforin. (A) is representative flow cytometric dot plots showing the percentages of $\mathrm{Mtb}$-specific or de novo production of granzyme with or without ex vivo stimulation of pooled Ag85-b/ESAT-6 peptides in $\mathrm{CD}^{+}$(or $\mathrm{CD}^{+}$) $\mathrm{T}$ cells from an individual with untreated active TB disease. A two-tiered gating system was used as well to analyze Mtb-specific or de novo perforin production by Tim-3expressing $\mathrm{CD}^{+}{ }^{+}$(or $\mathrm{CD}^{+}$) $\mathrm{T}$ cells, considering Tim- $3^{\mathrm{High}}$ and Tim- $3^{\text {Low }}$ subpopulations. Numbers in each of dot plot represent the percentages of granzyme B-producing $\mathrm{CD} 4^{+}$or $\mathrm{CD} 8^{+} \mathrm{T}$ cells. (D) is similar flow cytometric dot plots that were shown to analyze granzyme $\mathrm{B}$ expression in $\mathrm{CD}^{+}\left(\right.$or $\mathrm{CD}^{+}$) $\mathrm{T}$ cells from an individual with LTBI. (B) and (C) are pooled flow cytometric data from individuals with active TB disease $(n=9)$ showing that the percentages of granzyme $\mathrm{B}^{+} \mathrm{CD} 4^{+}\left(\right.$or $\left.\mathrm{CD}^{+}\right) \mathrm{T}$ cells are much higher in Tim- $3^{\mathrm{High}} \mathrm{CD} 4^{+}$(or CD8 ${ }^{+}$) $\mathrm{T}$ cells than their Tim-3 $3^{\text {Low }}$ counterparts. (E) and (F) are similar pooled flow cyotmetry data from individuals with LTBI $(n=9)$ showing that the percentages of granzyme $\mathrm{B}^{+} \mathrm{CD}^{+}{ }^{+}$or $\left.\mathrm{CD}^{+}\right) \mathrm{T}$ cells are much higher in Tim$3^{\text {High }} \mathrm{CD} 4^{+}$(or $\mathrm{CD}^{+}$) $\mathrm{T}$ cells than their Tim- $3^{\text {Low }}$ counterparts. Data shown are representative of at least three independent experiments. Error bars represent SD. $* p<0.05$, ** $p<0.01$, *** $p<0.001$.

(PDF)

Figure S8 Tim-3 expression is associated with stronger degranulation capability of Mtb-specific $\mathrm{CD4}^{+}$and $\mathrm{CD8}^{+}$ T cells. PBMCs derived from Mtb-infected individuals $(n=9)$ with untreated active TB disease were cultured in presence or absence of pooled Ag85-b/ESAT-6 peptides, and stained with fluorochrome-conjugated mAbs, followed by analysis using polychromatic flow cytometry. (A) is representative flow cytometric plots showing the percentages of CD107a expression with or without ex vivo stimulation of pooled Ag85-b/ESAT-6 peptides in Mtb-specific $\mathrm{CD}^{+}$and $\mathrm{CD}^{+} \mathrm{T}$ cells from an Mtb-infected individual with untreated active TB disease. (B) is complied flow cytometric data from Mtb-infected individuals $(n=9)$ showing that the percentages of Tim- $3{ }^{\mathrm{High}} \mathrm{CD} 4^{+} \mathrm{T}$ cells are much higher in $\mathrm{CD} 107 \mathrm{a}^{+} \mathrm{T}$ cells than those in CD107 $\mathrm{a}^{-} \mathrm{T}$ cells. (C) and (D) are representative flow cytometric data and summary bar graphic data, respectively, showing that similar stronger CD107a expression as like Tim- $3^{\mathrm{High}} \mathrm{CD} 4^{+} \mathrm{T}$ cells were also observed for Tim- 
$3^{\text {High }} \mathrm{CD}^{+}{ }^{+} \mathrm{T}$ cells. Data shown are representative of at least three independent experiments. Error bars represent SD. * $p<0.05$, $* * p<0.01, * * * \quad p<0.001$.

(PDF)

Figure S9 Stimulation of Tim-3 pathway using antiTim-3 Ab enhances the Mtb-specific effector functions of $\mathbf{C D 4}^{+}$and $\mathbf{C D 8}^{+} \mathbf{T}$ cells. PBMCs derived from Mtb-infected individuals $(\mathrm{n}=9)$ with untreated active TB disease were stimulated ex vivo using anti-Tim-3 mAb $(10 \mu \mathrm{g} / \mathrm{ml})$ or isotype control $\mathrm{Ab}(10 \mu \mathrm{g} / \mathrm{ml})$ in presence or absence of pooled Ag85-b/ ESAT-6 peptides for 6 days. Cells were then stained using ICS protocol, and analyzed by flow cytometry. (A) is typical flow cytometric dot plots showing the effect of Tim-3 stimulation using anti-Tim-3 mAb on Mtb-specific IFN- $\gamma$ response of Tim$3^{\text {High }} \mathrm{CD}^{+}{ }^{+} \mathrm{T}$ cells. Numbers in dot plots in each of sub-figure show the percentages of IFN- $\gamma^{+}$Tim $-3^{\mathrm{High}} \mathrm{CD} 4^{+} \mathrm{T}$ cells. $(\mathrm{C})$ is summary bar graphic data showing that Tim-3 stimulation using anti-Tim-3 mAb but not isotype control Ab significantly enhances the production of Mtb-specific IFN- $\gamma$ by Tim- $3^{\text {High }} \mathrm{CD} 4^{+} \mathrm{T}$ cells. (B) and (D) show that similar enhancement of Mtb-specific IFN- $\gamma$ responses upon stimulation with anti-Tim-3 mAb $(10 \mu \mathrm{g} / \mathrm{ml})$ were also observed in Tim- $3{ }^{\mathrm{High}} \mathrm{CD}^{+} \mathrm{T}$ cells. Data shown are

\section{References}

1. Maartens G, Wilkinson RJ (2007) Tuberculosis. Lancet 370: 2030-2043.

2. Cooper AM (2009) Cell-mediated immune responses in tuberculosis. Annu Rev Immunol 27: 393-422.

3. Chen CY, Huang D, Wang RC, Shen L, Zeng G, et al. (2009) A critical role for CD8 $\mathrm{T}$ cells in a nonhuman primate model of tuberculosis. PLoS Pathog 5: e1000392.

4. Kaufmann SH (2001) How can immunology contribute to the control of tuberculosis? Nat Rev Immunol 1: 20-30.

5. Flynn JL, Chan J (2001) Immunology of tuberculosis. Annu Rev Immunol 19: 93-129.

6. Woodworth JS, Wu Y, Behar SM (2008) Mycobacterium tuberculosis-specific CD8+ T cells require perforin to kill target cells and provide protection in vivo. J Immunol 181: 8595-8603.

7. Sabatos CA, Chakravarti S, Cha E, Schubart A, Sanchez-Fueyo A, et al. (2003) Interaction of Tim-3 and Tim-3 ligand regulates T helper type 1 responses and induction of peripheral tolerance. Nat Immunol 4: 1102-1110

8. Sanchez-Fueyo A, Tian J, Picarella D, Domenig C, Zheng XX, et al. (2003) Tim-3 inhibits T helper type 1-mediated auto- and alloimmune responses and promotes immunological tolerance. Nat Immunol 4: 1093-1101.

9. Zhu C, Anderson AC, Schubart A, Xiong H, Imitola J, et al. (2005) The Tim-3 ligand galectin-9 negatively regulates T helper type 1 immunity. Nat Immunol 6 : 1245-1252.

10. Sharpe AH, Wherry EJ, Ahmed R, Freeman GJ (2007) The function of programmed cell death 1 and its ligands in regulating autoimmunity and infection. Nat Immunol 8: 239-245.

11. Trautmann L, Janbazian L, Chomont N, Said EA, Gimmig S, et al. (2006) Upregulation of PD-1 expression on HIV-specific CD8+ $\mathrm{T}$ cells leads to reversible immune dysfunction. Nat Med 12: 1198-1202.

12. Zhu Y, Yao S, Chen L (2011) Cell surface signaling molecules in the control of immune responses: a tide model. Immunity 34: 466-478.

13. Kaufmann DE, Kavanagh DG, Pereyra F, Zaunders JJ, Mackey EW, et al. (2007) Upregulation of CTLA-4 by HIV-specific CD4+ T cells correlates with disease progression and defines a reversible immune dysfunction. Nat Immunol 8: $1246-1254$.

14. Vali B, Jones RB, Sakhdari A, Sheth PM, Clayton K, et al. (2010) HCV-specific $\mathrm{T}$ cells in HCV/HIV co-infection show elevated frequencies of dual Tim-3/PD1 expression that correlate with liver disease progression. Eur J Immunol 40: 2493-2505.

15. Jin HT, Anderson AC, Tan WG, West EE, Ha SJ, et al. (2010) Cooperation of Tim-3 and PD-1 in CD8 T-cell exhaustion during chronic viral infection. Proc Natl Acad Sci U S A 107: 14733-14738.

16. Golden-Mason L, Palmer BE, Kassam N, Townshend-Bulson L, Livingston S, et al. (2009) Negative immune regulator Tim-3 is overexpressed on T cells in hepatitis $\mathrm{C}$ virus infection and its blockade rescues dysfunctional CD4+ and CD8+ T cells. J Virol 83: 9122-9130.

17. Sakuishi K, Jayaraman P, Behar SM, Anderson AC, Kuchroo VK (2011) Emerging Tim-3 functions in antimicrobial and tumor immunity. Trends Immunol 32: 345-349.

18. Wang X, Cao Z, Jiang J, Li Y, Dong M, et al. (2011) Elevated expression of Tim-3 on CD8 T cells correlates with disease severity of pulmonary tuberculosis. J Infect 62: 292-300. representative of at least three independent experiments. Error bars represent SD. ** $p<0.01$, *** $p<0.001$, NS, no statistical significance.

(PDF)

Table S1 Clinical characteristics of the enrolled subjects.

(PDF)

\section{Acknowledgments}

We thank Shenzhen Key Clinical Department of Emerging Infectious Diseases and nurses, doctors and staffs in Shenzhen Third People's Hospital for clinical management of patients and research coordination in this work.

\section{Author Contributions}

Conceived and designed the experiments: Z.W. Chen, G. Zeng, L. Jiang, J. Cai, L. Shen, K. Cao, Y. Zhang, H.Wang. Performed the experiments: Y. Qiu, J. Chen, H. Liao, S. Li, Y. Luo, D. Fang, G. Li, C.Y. Chen, D.Huang. Analyzed the data: Y. Qiu, J. Chen, H.Liao, S. Li, G. Li, C.Y. Chen, D. Huang. Contributed reagents/materials/analysis tools: J. Chen, G. Li, B. Zhou. Wrote the paper: Z.W. Chen, G. Zeng.

19. Jones RB, Ndhlovu LC, Barbour JD, Sheth PM, Jha AR, et al. (2008) Tim-3 expression defines a novel population of dysfunctional $\mathrm{T}$ cells with highly elevated frequencies in progressive HIV-1 infection. J Exp Med 205: 2763-2779.

20. McMahan RH, Golden-Mason L, Nishimura MI, McMahon BJ, Kemper M, et al. (2010) Tim-3 expression on PD-1+ HCV-specific human CTLs is associated with viral persistence, and its blockade restores hepatocyte-directed in vitro cytotoxicity. J Clin Invest 120: 4546-4557.

21. Ju Y, Hou N, Meng J, Wang X, Zhang X, et al. (2010) T cell immunoglobulinand mucin-domain-containing molecule-3 (Tim-3) mediates natural killer cell suppression in chronic hepatitis B. J Hepatol 52: 322-329.

22. Hafler DA, Kuchroo V (2008) TIMs: central regulators of immune responses. J Exp Med 205: 2699-2701.

23. Sakuishi K, Apetoh L, Sullivan JM, Blazar BR, Kuchroo VK, et al. (2010) Targeting Tim-3 and PD-1 pathways to reverse T cell exhaustion and restore anti-tumor immunity. J Exp Med 207: 2187-2194.

24. Fourcade J, Sun Z, Benallaoua M, Guillaume P, Luescher IF, et al. (2010) Upregulation of Tim-3 and PD-1 expression is associated with tumor antigen-specific CD8+ T cell dysfunction in melanoma patients. J Exp Med 207: 2175-2186.

25. Oiu L, Huang D, Chen CY, Wang R, Shen L, et al. (2008) Severe tuberculosis induces unbalanced up-regulation of gene networks and overexpression of IL-22, MIP-1alpha, CCL27, IP-10, CCR4, CCR5, CXCR3, PD1, PDL2, IL-3, IFN-beta, TIM1, and TLR2 but low antigen-specific cellular responses. J Infect Dis 198: 1514-1519.

26. Walzl G, Ronacher K, Hanekom W, Scriba TJ, Zumla A (2011) Immunological biomarkers of tuberculosis. Nat Rev Immunol 11: 343-354.

27. Hamann D, Baars PA, Rep MH, Hooibrink B, Kerkhof-Garde SR, et al. (1997) Phenotypic and functional separation of memory and effector human CD8+ T cells. J Exp Med 186: 1407-1418.

28. Sallusto F, Lenig D, Forster R, Lipp M, Lanzavecchia A (1999) Two subsets of memory $\mathrm{T}$ lymphocytes with distinct homing potentials and effector functions. Nature 401: 708-712.

29. Champagne P, Ogg GS, King AS, Knabenhans C, Ellefsen K, et al. (2001) Skewed maturation of memory HIV-specific CD8 T lymphocytes. Nature 410: $106-111$.

30. Bruns H, Meinken C, Schauenberg P, Harter G, Kern P, et al. (2009) Anti-TNF immunotherapy reduces CD8+ T cell-mediated antimicrobial activity against Mycobacterium tuberculosis in humans. J Clin Invest 119: 1167-1177.

31. Sallusto F, Geginat J, Lanzavecchia A (2004) Central memory and effector memory $\mathrm{T}$ cell subsets: function, generation, and maintenance. Annu Rev Immunol 22: 745-763.

32. Yao S, Huang D, Chen CY, Halliday L, Zeng G, et al. (2010) Differentiation, distribution and gammadelta T cell-driven regulation of IL-22-producing T cells in tuberculosis. PLoS Pathog 6: e1000789.

33. Ryan-Payseur B, Ali Z, Huang D, Chen CY, Yan L, et al. (2011) Virus infection stages and distinct Th1 or Th17/Th22 T-cell responses in malaria/SHIV coinfection correlate with different outcomes of disease. J Infect Dis 204: 1450-1462.

34. Zeng G, Chen CY, Huang D, Yao S, Wang RC, et al. (2011) Membrane-bound IL-22 after de novo production in tuberculosis and anti-Mycobacterium tuberculosis effector function of IL-22+ CD4+ T cells. J Immunol 187: 190-199.

35. Monney L, Sabatos CA, Gaglia JL, Ryu A, Waldner H, et al. (2002) Th1-specific cell surface protein Tim-3 regulates macrophage activation and severity of an autoimmune disease. Nature 415: 536-541. 
36. Kuchroo VK, Umetsu DT, DeKruyff RH, Freeman GJ (2003) The TIM gene family: emerging roles in immunity and disease. Nat Rev Immunol 3: 454-462.

37. Jayaraman P, Sada-Ovalle I, Beladi S, Anderson AC, Dardalhon V, et al. (2010) Tim3 binding to galectin-9 stimulates antimicrobial immunity. J Exp Med 207: 2343-2354.

38. Koul A, Herget T, Klebl B, Ullrich A (2004) Interplay between mycobacteria and host signalling pathways. Nat Rev Microbiol 2: 189-202.

39. Kaech SM, Tan JT, Wherry EJ, Konieczny BT, Surh CD, et al. (2003) Selective expression of the interleukin 7 receptor identifies effector CD8 T cells that give rise to long-lived memory cells. Nat Immunol 4: 1191-1198.

40. Ali Z, Shao L, Halliday L, Reichenberg A, Hintz M, et al. (2007) Prolonged (E)4-hydroxy-3-methyl-but-2-enyl pyrophosphate-driven antimicrobial and cytotoxic responses of pulmonary and systemic Vgamma2Vdelta2 $\mathrm{T}$ cells in macaques. J Immunol 179: 8287-8296.

41. Lee J, Su EW, Zhu C, Hainline S, Phuah J, et al. (2011) Phosphotyrosinedependent coupling of Tim-3 to T-cell receptor signaling pathways. Mol Cell Biol 31: 3963-3974.

42. Wang X, Barnes PF, Dobos-Elder KM, Townsend JC, Chung YT, et al. (2009) ESAT-6 inhibits production of IFN-gamma by Mycobacterium tuberculosisresponsive human T cells. J Immunol 182: 3668-3677.
43. Cooper AM, Dalton DK, Stewart TA, Griffin JP, Russell DG, et al. (1993) Disseminated tuberculosis in interferon gamma gene-disrupted mice. J Exp Med 178: 2243-2247.

44. Flynn JL, Goldstein MM, Chan J, Triebold KJ, Pfeffer K, et al. (1995) Tumor necrosis factor-alpha is required in the protective immune response against Mycobacterium tuberculosis in mice. Immunity 2: 561-572.

45. Flynn JL, Chan J, Triebold KJ, Dalton DK, Stewart TA, et al. (1993) An essential role for interferon gamma in resistance to Mycobacterium tuberculosis infection. J Exp Med 178: 2249-2254.

46. MacMicking JD, Taylor GA, McKinney JD (2003) Immune control of tuberculosis by IFN-gamma-inducible LRG-47. Science 302: 654-659.

47. Botha T, Ryffel B (2003) Reactivation of latent tuberculosis infection in TNFdeficient mice. J Immunol 171: 3110-3118.

48. Dieli F, Sireci G, Caccamo N, Di Sano C, Titone L, et al. (2002) Selective depression of interferon-gamma and granulysin production with increase of proliferative response by Vgamma9/Vdelta2 $\mathrm{T}$ cells in children with tuberculosis. J Infect Dis 186: 1835-1839.

49. Clay H, Volkman HE, Ramakrishnan L (2008) Tumor necrosis factor signaling mediates resistance to mycobacteria by inhibiting bacterial growth and macrophage death. Immunity 29: 283-294. 